\title{
The rise of public schooling in nineteenth-century Imperial Austria: Who gained and who paid?
}

\author{
Tomas Crrcek ${ }^{1}$ (D) $\cdot$ Miroslav Zajicek ${ }^{2,3,4}$
}

Received: 4 September 2017 / Accepted: 8 October 2018 / Published online: 26 October 2018

(c) The Author(s) 2018

\begin{abstract}
The rise of education features prominently in the debate on the sources of modern economic growth. Existing accounts stress the importance of popular demand for its public provision. We argue that such an explanation for the spread of schooling is a poor fit for many nations' schooling histories, such as Imperial Austria. We show that in the Austrian case, schooling and economic development had limited impact on each other; that the popular demand for schooling was weak and that the push for school expansion came mainly from the top of the political hierarchy.
\end{abstract}

Keywords Public schooling $\cdot$ Education $\cdot$ Economic development $\cdot$ Austria

JEL Classification $\mathrm{N} 13 \cdot \mathrm{I} 25 \cdot \mathrm{I} 28$

\section{Introduction}

Across the industrialized world, economic modernization historically went hand in hand with the emergence of modern mass schooling. Not surprisingly, the existence and strength of the causal link between schooling and economic development has been investigated in numerous cross-sectional regressions (Sala-i-Martin 1997; Hanushek and Woessmann 2012). Proposals regarding the provision of schooling count among core policy recommendations issued to developing countries around the world (Easterlin 1981). But apart from these economic considerations, primary and secondary education has also historically served as a vehicle of political

Tomas Cvrcek

t.cvrcek@ucl.ac.uk

1 School of Slavonic and East European Studies, University College London, 16 Taviton Street, London, UK

2 Faculty of Law, Charles University, Prague, Czech Republic

3 Faculty of Business and Economics, Mendel University in Brno, Brno, Czech Republic

4 UCL Center for Comparative Studies of Emerging Economies, London, UK 
socialization through inculcation of specific cultural values and through building a sense of shared history and national allegiance (Glaeser et al. 2007; Bandiera et al. 2016; Pritchett and Viarengo 2015).

The politics and the economics of mass schooling have always been intertwined, given the prominent role played by the public sector in this area (Lindert 2004: Chapter 5). What a particular educational system is supposed to achieve-whether development, or socialization or some combination of both-and who supports its creation and pays for it - whether the elites or the masses - are closely related questions because particular political constituencies support particular schooling policies, expecting particular benefits in return for their support. Our aim in this paper is to ask precisely these interconnected questions in case of the schooling system introduced in late eighteenth and early nineteenth century in Imperial Austria.

As we discuss in greater detail in Sect. 2, when the masses support schooling, they expect to benefit from the economic advance and modernization that it enables. In those circumstances, traditional elites (such as landed aristocracy) are usually the main bulwark of opposition. This line of argument, recently revisited by Lindert (2004), Go and Lindert (2010), Mariscal and Sokoloff (2000) and others, sees modern growth as a consequence of (among other things) the rise of national public systems of education which themselves were the product of broadened political voice and mass electoral support for tax-based schooling. An alternative line of reasoning sees traditional elites as supportive of mass schooling, when such schooling served to reinforce traditional political structures while posing limited risk of disruptive economic transformation. Under such conditions, it is quite conceivable to have a long-standing schooling system with an almost universal reach and generating high levels of educational attainment (measured in years of schooling), which nonetheless has limited impact on economic development.

We argue that the schooling system introduced by the Habsburg emperors in late eighteenth and early nineteenth century was of this latter kind. We build our case in three steps. First, we describe the regulation pertaining to elementary schooling, which we take at face value as an expression of the preferences of the ruling elites. We show that this regulation downplayed the importance of teacher training and was even suspicious of "too much knowledge" (Engelbrecht 1986). Teaching practical (and marketable) knowledge and skills beyond rudimentary literacy and numeracy - what German pedagogy then called Realia - was of second-order importance in the curriculum, while religious instruction stressing obedience, loyalty and social conservatism was prominent. Next, we investigate whether schooling in its mandated form enhanced the sophistication and human capital intensity of the local labor market, thereby giving the masses an avenue for economic advance and consequently a reason to support it. We do not find evidence of such positive impact, except in places (mainly towns) where the curriculum was broad enough to include some instruction in practical knowledge. Finally, we look at various constituencies' readiness to contribute to this public good. Using the Austrian institution of school patronage (Schulpatronat), we show that the central authorities and aristocratic elites, not the mass of villagers in local communities, were the most determined and single-minded, if not always successful, force for the extension of schooling in Austria. The policy makers controlled the content of education but (perhaps 
as a result) continued to be frustrated in their efforts to spread it to such extent, as they desired. The general population in towns and villages mostly proved reluctant to make good on (let alone go beyond) the existing regulations. Thus, in contrast to the usual upbeat story of newly enfranchised but credit-constrained masses wisely voting themselves more public school provision to be financed by stingy elites to further the economic fortunes of their children and their country, we describe a system where the elite foisted a politically motivated education on lukewarm masses while making them pay for it mostly out of their own pockets-all with predictably mixed results.

One advantage of centrally mandated schooling systems, such as the Austrian one, is that they were often accompanied by extensive data collection at several levels of aggregation, allowing us to investigate these issues in close range. In 1865, the government commissioned the first comprehensive school census which reported detailed information on staff, curriculum and enrollment for each of the almost 11.000 schools across Imperial Austria (K.K. Statistische Zentral-Commission 1870). We merge this dataset with the 1863 empire-wide census of all steam engines (our proxy for local level of technological sophistication) and with the 1869 population census. We use the data on employment structure to construct a measure of the human capital intensity of the local labor market and analyze its variation in relation to local schooling supply, using a simultaneous equations model. Finally, for one of the provinces, Lower Austria, we were able to locate an 1852 teacher and school directory which, when linked with school-level data from the 1865 survey, allows us to go all the way down to the level of individual schools and their school patrons and investigate change in school provision across time at school level (Kaiser 1852).

Our results have implications for how we evaluate the impact of schooling on economic growth. Whether a particular educational system "contributed" to a country's development or whether it "failed" cannot be measured just in terms of enrollment, the staff availability and the level of public expense. Public spending on schooling is an investment that may or may not bear a return depending on how well that investment is made (Hanushek 2013). If such an investment yields scant returns or if the education is supplied beyond where benefits cover the costs on the margin, then the public outlay, in whole or in part, may represent a deadweight loss. In those instances, high enrollment and high public outlays are not a boon to the economy but only a costly burden.

\section{Expansion of schools: existing explanations}

Many existing accounts explain the rise of modern schooling in a bottom-up fashion, almost as a grassroots movement. The underlying logic is that universal access to productivity-boosting skills held the promise of lifting large swathes of the population from poverty and the masses therefore supported expansion of tax-financed education. It is in this context that Lindert (2004: 87) called public schooling expenditure "the most positively productive kind of spending" and "the greatest shift of resources from upper income groups to the poor". The notion of schooling as a skill-generator also underpins, for example, the debate about the contribution of 
popular Prussian primary education to Germany's economic ascendancy during the Second Industrial Revolution (Becker et al. 2011); the concurrent failure of British educational system to keep up with Germany (Lindert 2004: 113-115; Galor 2011: $34)$; the role of the American high school in the "the race between education and technology" (Goldin and Katz 2008).

But this framework underplays the fact that the very same education systems also served as tools of nation building through socialization (even indoctrination) of pupils. Cinnirella and Schueler (2016) show that primary schooling of Imperial Germany increased the vote for nationalist parties because it was partly designed to produce "loyal citizens," while Bandiera et al. (2016) explain the emergence of compulsory schooling laws in US states toward the end of the nineteenth century as means to facilitate integration of immigrants into the American body politic. In the context of twentieth-century Portugal, Palma and Reis (2018: 5-6) document the deeply ideological view of education under both the First Republic (1910-1926) and the authoritarian Estado Novo (1926-1974). Historically, nation-building efforts drew on any number of motivations, be they the need to face down an outside threat (Aghion et al. 2012), or a totalitarian government's efforts to shore up its ideological hegemony through indoctrination (Lott 1999). In this telling, the main reason why modern schooling became universal, public and highly politicized was because its creation was informed by "an endeavor to construct a unified national polity" (Ramirez and Boli 1987: 3).

Intuitively, the political alignments either in favor or against public education correspond with each constituency's perceived costs and benefits. Mass education systems geared toward equipping the masses with necessary skills for the modern economy will likely ensure a broad popular support, given the private returns to skill on the labor market. Although skill instruction can be easily supplied privately (Pritchett and Viarengo 2015), the masses are likely to support public provision of schooling, if such instruction is expensive. On the other hand, ruling elites may plausibly support a nation-building schooling system, which would socialize the populace into accepting existing political realities. Such school system designed to just inculcate subservience is likely to leave the general population indifferent.

Analogously, landowners can be expected to oppose education complementary to industrialization as it may reduce land rents (Galor et al. 2009). This "Tory opposition theory" (Lindert 2004: 100) has been investigated in numerous contexts, although the method of obstruction ascribed to landowners, varies across researchers. The less obvious and less frequently invoked is a demand-side argument whereby high inequality of land ownership implied a large population of landless, poor or enserfed agricultural laborers whose incentives to acquire human capital were weak (Beltran and Martinez-Galarraga 2015; Cinnirella and Hornung 2016). The more straightforward manner of obstruction was by political opposition. It took primarily the form of limitation of suffrage, as argued by Sokoloff and Engerman (2000) and Mariscal and Sokoloff (2000) for the case of Latin America and by Gallego (2010) for all former colonies. In the opposite direction, Go and Lindert (2007, 2010) showed a positive effect of broader suffrage on enrollment and on public spending per pupil. But even in the context of universal suffrage, landed elites 
could win out just by being better politically organized (Ramcharan 2010: 729; Goni 2017). Vollrath (2013) documents that more skewed farm-size distribution had negative effect on tax revenue of local school districts in the USA of 1890, which, again, most likely operated through local elections. The notion that the extension of suffrage or some other way of voicing keenly felt popular demand for education led to an increased local public provision of schooling reappears in explanations for many countries through many epochs, e.g., Brazil in 1890-1930 (Musacchio et al. 2014), post-1860 Russia (Nafziger 2011), early nineteenth-century Britain (Mitch 2012) or early twentieth-century BRICs (Chaudhary et al. 2012).

In contrast to these narratives of landed opposition, our contribution is to present and analyze a case of a schooling system supported and promoted by the ruling (and landowning) elite. In the Habsburg Empire, the original and continuing impetus for the spread of primary schooling came decidedly from the top of the political hierarchy. It was also a schooling system heavily focused on particular political socialization and suspicious of extensive skill acquisition. Ficker (1873) documents, for example, that for the whole first half of the nineteenth century, the Austrian government pushed for the spread of primary schooling but resisted the growth of secondary, particularly technical, schooling.

What about the masses living under the Habsburg scepter? The Austrian historical context makes measuring popular political voice difficult. Go and Lindert's (2010) choice of votes cast in presidential elections makes sense in the context of American political institutions but for most countries such measure is too restrictive, if it exists at all. Many European countries at the time of Industrial Revolution had scarcely any democratic institutions, and the cross-sectional variation in suffrage, where it existed, was small. Special interests and various constituencies still found ways to voice their concerns but the political voice was much less formalized and thus harder to measure. We exploit the fact that while the oversight over content of education was centralized and tightly controlled, the school financing was mostly local with some selective subsidization from the center. We interpret the readiness of various constituencies to financially contribute to schools as a measure of their support for this system.

\section{The institutional framework}

Already at its inception in 1774, the Austrian schooling system was informed by the ruler's intention to use it as a tool for state building and political control. The keenly felt need to bolster waning seigneurial authority on aristocratic estates by inculcating discipline in serfs, the recognition that literate culture was easier to censor than purely oral one as well as (overwrought) worries about the spread of crypto-Protestantism all coalesced into a school reform plan that aimed to be universal in its reach and firmly in control of the curriculum (Melton 1988). The Allgemeine Schulordnung of 1774, the basic law on systematic primary schooling, introduced several basic long-lasting features, such as the compulsory schooling for both boys and girls aged 6-12, the distinction between country schools and town schools, the compulsory certification of teachers, including private tutors, and the stress on religion and 
the trivium. In 1805, this law was replaced by the "Political Constitution of German Schools" (Politische Verfassung der deutschen Volksschulen)—a much more detailed, comprehensive regulation, which remained in force until 1869 (and which informs our analysis in the rest of the paper). In some 478 detailed, micromanaging articles, the law regulated everything including the size of school desks (Article 356), size of classrooms (Art. 365), approved textbooks (Art. 321), length of school day (Art. 80), method of instruction ${ }^{1}$ (Art. 38), minimum teacher salary (Art. 167) and even pupils' attire on examination day (Art. 91). It also established education monopoly for government schools by outlawing unauthorized, private "backstreet teachers," Winkellehrern (Art. 128 and 344), who throughout the eighteenth century had been offering quick, cheap instruction in reading and writing in numerous central-European cities.

Regulation of the curriculum left little doubt that the main purpose of the school was proper socialization, as opposed to learning practical knowledge. Article 28 declared religion the most important subject. In countryside schools, the legally mandated lesson plan specified that catechism and biblical history take up six out of eighteen weekly lessons for the 9-12-year-olds and four out of nine weekly lessons for the 6-8-year-olds. The law stipulated that a school day should begin or end with a lesson of religion (Art. 82) and mastery of the religious content (not of literacy) was a prerequisite for progressing to a higher grade (Art. 66). Article 41 stressed that the purpose of the religious instruction was to inculcate willing compliance in the peasants, thereby echoing a century-old tradition in pedagogical thought of viewing schooling as a tool of social control (Melton 1988: 38-40). The system also betrayed a preference for (though not insistence on) instruction in German. Textbooks for non-German nationalities were bilingual, and teachers were expected to be conversant in German, whatever their mother tongue (Art 217-218). Cases where "Romanian children were taught in Polish to read from a German textbook" (Prausek 1868: 6) opened the system to accusations of both inefficiency and Germanization. ${ }^{2}$

Writing, reading and counting were next in importance after religion, apportioned equally across the remaining weekly lessons. The authorities apparently realized that a successful strategy against unauthorized teaching would require meeting the urban demand for literacy and other skills half way but such instruction was granted reluctantly: The law warned against "excessive knowledge" and considered teaching it to all social classes a "major error in public education" (Art. 28, 44). As for literacy and numeracy, Articles 315-316 specified that first-grade pupils should only learn

\footnotetext{
1 Article 38 stated that "the Bell-Lancaster method" of peer learning, then popular in England, "was banished from our class-rooms." Post-1848, teachers had somewhat more leeway in choosing their teaching approach but, for various reasons, only few teachers took up the opportunity to update their methods (Ficker 1873: 40).

2 The revolutions of 1848 produced a few changes in legislation, most notably an explicit statement in favor of instruction in one's mother tongue, freedom of teaching methods, an optional expansion of primary schools from two grades to three grades and an extension of teaching colleges from one year to two. But other attempts at liberal education were soon quashed through the Concordat of 1855, which put the Church yet again firmly in charge of the school supervision and teacher appointments. Even the language provisions were less than perfectly enforced and the freedom of teaching method fell flat.
} 
to recognize letters, learn basic pen strokes and learn rudimentary mental arithmetic. The second grade would introduce reading of short stories, writing to dictation, penmanship and written calculation. Not much practical, functional literacy could be expected among pupils after the first two grades. Only in the third grade would the students be exposed to the four primary arithmetic operations and the rule of three (Art. 33). Only from the third grade on would they also learn basic composition, such as writing an official letter. The fourth grade also offered basic geometry, history, geography of the Empire and even what one may translate as basic structural design (Baukunst). In short, while the first two grades offered little beyond rudimentary literacy, the third and fourth grades used literacy and numeracy as building blocks for further skills that one may reasonably see as practical and therefore marketable.

Importantly, most children were never to enter the third grade or beyond because the law expected most schools to be two-grade schools. Children would spend 2 years in the first grade before progressing to the second grade for their remaining school years. Rural schools especially were envisioned as two-grade. Although they were not explicitly prohibited from opening a third grade, some of the law's provisions implied that progression to a third grade presupposed a transfer from rural to a town school (Art. 65). The law distinguished between rural and urban education, of which the latter was a little more sophisticated: Town schools taught from somewhat different textbooks than country schools, and their teaching was to reflect the pupils' greater exposure to trade and urban life (Art. 43). Of course, in the context of the first half of the nineteenth century, "town" referred to the traditional local market centers, not sprawling new industrial cities. At any rate, the Habsburg Empire had few of either.

Conveniently, this contrast, embedded in the law, between a narrow curriculum of bare literacy for the rural majority and a somewhat more extensive one for a small minority of urban pupils finds an interesting labor market counterpart in Mokyr's (2005: 1160) observation regarding the distribution of human capital in the workforce during the period of the First Industrial Revolution: The "technological changes of the nineteenth century created a demand for highly skilled mechanics and engineers in the upper tail of the distribution, while possibly reducing the need for skills among manual laborers" (Mokyr and Voth 2010: 29). Consequently, "the modal level of knowledge" was low, but the variance in skill distribution probably rose. The Austrian elementary school certainly did not produce engineers and mechanics but the weekly three hours of geometry, two hours of Baukunst and ten hours of drawing in the third and fourth grades of town schools could plausibly help the pupils to eventually become workers "who could accurately produce the parts, using the correct dimensions and materials, [or] who could read blueprints" (Mokyr 2005: 1159). In short, a path to such skills did exist in the system of Austrian schooling, but it was closed to almost all pupils, except for a lucky (urban) few who had the opportunity to become the upper tail of the skill distribution among workers.

While the law constrained access to practical skills, it was very adamant about subjecting all children to the socializing parts of education. In order to ensure adequate infrastructure, various stakeholders were obligated to supply the resources for school provision (construction, maintenance, teacher salary and accommodation). In 


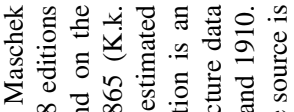

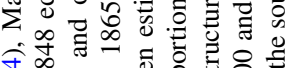

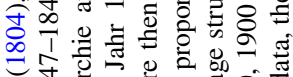

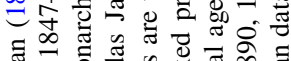

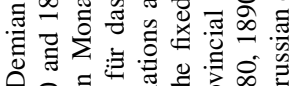

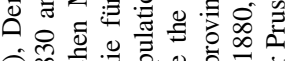

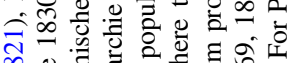
을 은

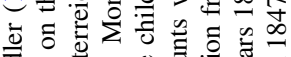

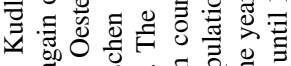

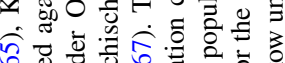

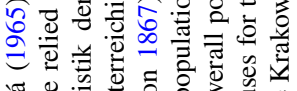

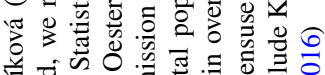

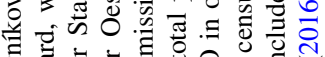

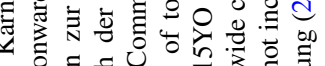

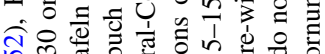
$\infty$ 辰可 포풀 我

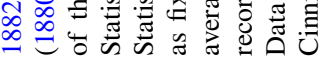

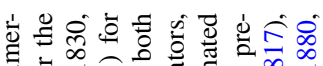

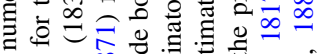

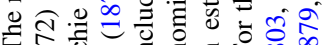

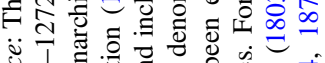

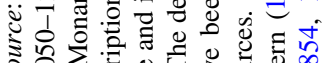

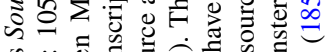

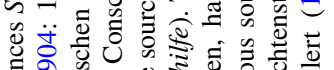

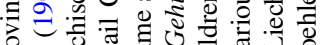

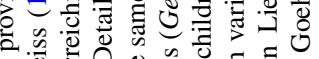
政

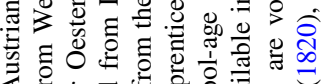

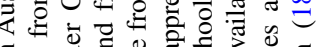
s

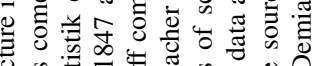

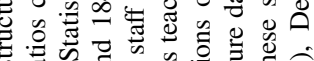

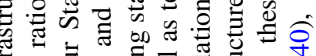

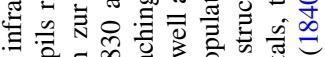
-

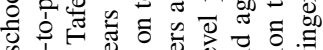

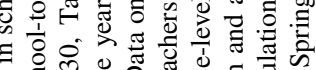

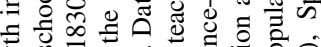
施 of

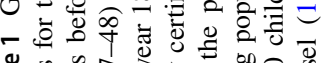

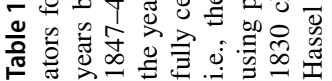

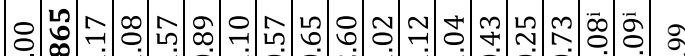
N

定

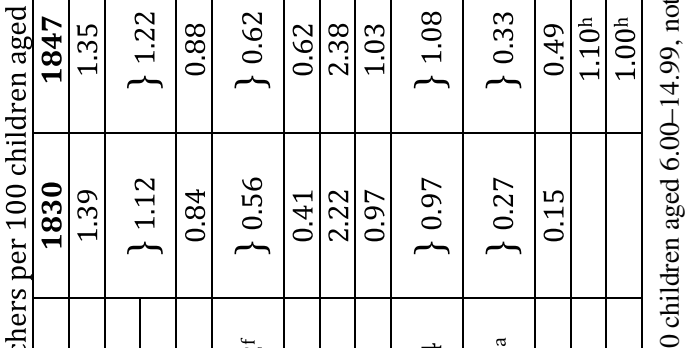

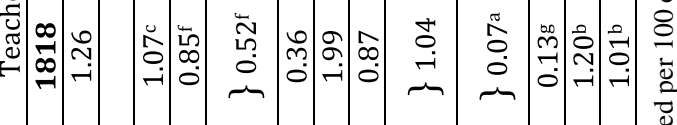

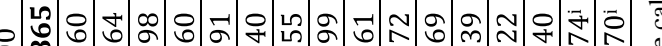

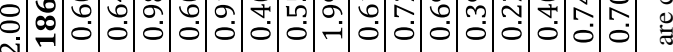
i

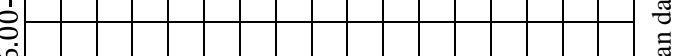

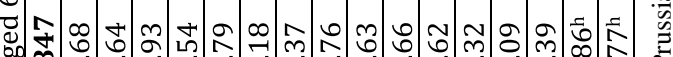

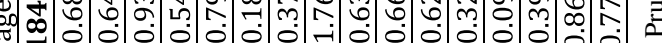

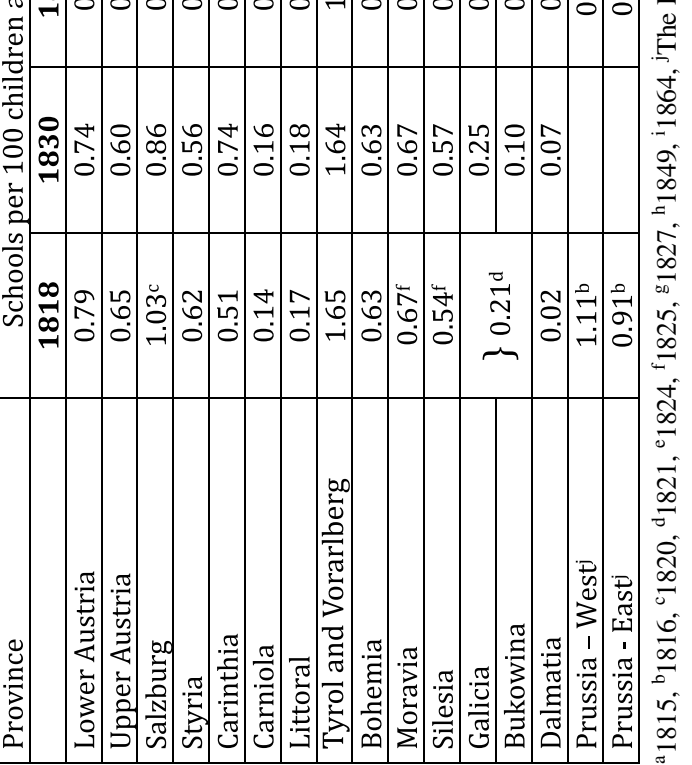


principle, in every parish and wherever 100 school-age children lived within halfhour of walking distance, a school was to be built (Art. 17 and 336-338) with ideally 80 but certainly no more than 100 pupils per classroom and per teacher (Art. 346-352). Yet, the reality, depicted in Table 1, did not always conform to regulation. This was particularly the case with physical infrastructure, which in many provinces struggled to even just keep pace with population growth. A few urban schools contained more than one classroom and were therefore able to accommodate even several hundred students but the bulk of schools were modest one-classroom affairs and so values below 1 in Table 1 are a reasonable indication that many schools crowded in well over 100 pupils per classroom. The regulators were aware of the problem, which is why the law allowed such overcrowded schools, as a temporary measure of last resort, to split the school day into morning instruction for grade 2 (9-12-yearolds) and afternoon instruction for grade 1 (6-8-year-olds) (Art. 81 and 314). Only Tyrol consistently reported values above 1 , because this mountainous Alpine region required a separate school in practically every village. ${ }^{3}$ The availability of teaching staff was somewhat better although even here some provinces did not quite keep up with the student population. For both schools and teachers, however, Austrian provinces were far behind Prussia (note that the Prussian statistics are calculated per 100 pupils aged 6-14, not 6-12).

Financing of these newly mandated schools was a perennial problem. The authorities did not want to make public schooling unpopular from the outset by levying a specific, earmarked school tax (Ficker 1873: 22). Instead, to put school financing on a more systematic footing, the government obliged manorial lords to supply firewood to schools and eventually introduced, for all other maintenance costs, the institute of school patronage (Schulpatronat) in 1787, which remained in place until the early 1860s. In this arrangement, the school financing was hitched onto a previously existing system of church patronage: Whoever had been responsible for the upkeep of local church-whether the local landowner, a government fund, a religious order, a free town - was now also saddled with contributions to the financing of local school. ${ }^{4}$ As the system settled down in early nineteenth century, the school patrons contributed to maintenance and repairs (Art. 389) as well as teaching aids (Art. 383), and, until 1848, were also responsible for co-financing new classroom construction, when it was necessary (Frank 1898a: 22). This last obligation became negotiable when serfdom and patrimonial administration were abolished in 1848 (Helfert 1860: 140). Throughout its existence, the Schulpatronat engendered

\footnotetext{
${ }^{3}$ The Tyrolean schools only convened for half a year for various local reasons. Moreover, Austrian statistics made no conceptual distinction between enrollment and attendance even though from the context of the operation of the schools, it is clear that they were enrollment numbers. As a result, even identical enrollment records of two distinct provinces may be associated with very different amounts of education provided to local pupils.

${ }^{4}$ In this way, even the Emperor and certain institutions of central government entered into school patronage, such as on Crown estates or on the estates of former Jesuit order, whose property was confiscated by the government, when the order was abolished. Therefore, not only was the central government the ultimate arbiter in general schooling policy matters for all schools, it was also a local stakeholder for those schools where it served as the school patron.
} 


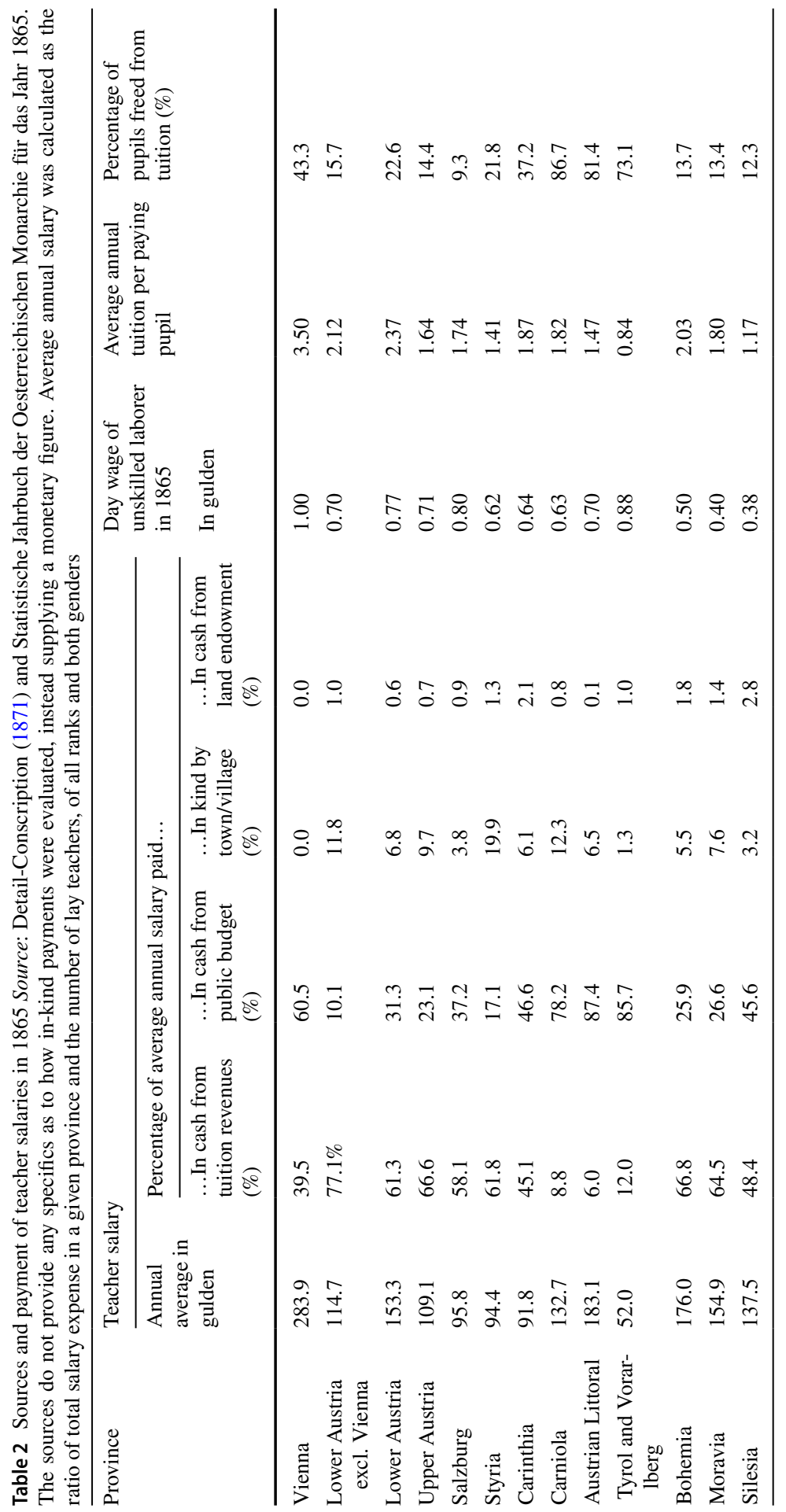


considerable dissatisfaction on all sides because it required complex negotiations between numerous parties about obligations (Art. 397) and once a constitutional, representative government was introduced in 1861, provincial assemblies abolished it within their first term of office. While it lasted, however, the Schulpatronat was the primary channel through which the landed (and other) elites were made to contribute directly to the financing of local schools, specifically of the physical infrastructure.

The local communities-towns, villages, parishes-were to take care of the teacher salary (Art. 197). Table 2 shows how varied the salaries and their sources were. There is no obvious pattern to why some provinces relied primarily on the public purse while others levied more tuition but the contrasts were quite stark. Tyrol, Littoral and Carniola let most pupils enroll free of charge and paid most of the salary out of public budgets, while in Bohemia, Moravia and Upper Austria, two-thirds of the teacher salary came from tuition. The salaries did not hold up well even against wages for unskilled labor (Cvrcek 2013). ${ }^{5}$ Yet, given that teacher salaries represented the bulk of the cost of school provision, Table 2 suggests that these costs were mainly passed onto the local population and often specifically onto the pupils' families, while landed elites contributed little to salary outlays. ${ }^{6}$

The purpose of this detailed exposition is to place the Austrian schooling system in the context of the existing debate, outlined in Sect. 2, and to carefully locate, by a close reading of the regulation, the fault lines between the country and the city, between the socializing two-grade education and potentially skill-enhancing thirdor higher-grade education, and between the landed elites and other stakeholders. As is clear from the institutional exposition, the elites affected schooling at two levels: at the highest, policy-making level in Vienna and at the more local, school-patronage level where the ins and outs of financing were being negotiated. We assume that at the policy-making level, the elite's preferences were expressed in the enacted regulations, which shaped the system to the extent that they were successfully enforced. We analyze this impact in Sect. 5. On the local level, we study the landed elites' support for schooling (or lack thereof) by comparing the fruits of their contribution to financing schools relative to those of other constituencies. This is reported in Sect. 6.

\section{Our data}

We make use of the rich detail of schooling information in the Habsburg school census of 1865 and combine it with data on local economic development, such as employment structure, local railroad access and use of steam power to investigate

\footnotetext{
5 Note that, in line with an earlier footnote, the Tyrolean teachers in most schools were only paid for half a year of teaching.

${ }^{6}$ Kneidl (1898) cites several examples of a Fassa, an annual itemized account of school-related expenses, compiled by each teacher for his school. They show that, by and large, the only expense item that was not directly tied to teacher remuneration was classroom firewood.
} 
Table 3 Descriptive statistics

\begin{tabular}{|c|c|c|c|c|c|}
\hline \multirow[t]{2}{*}{ Variable } & \multicolumn{2}{|l|}{ Overall } & \multicolumn{3}{|c|}{ District means } \\
\hline & Mean & Std. Dev. & Urban & Rural & $t$ test \\
\hline $\begin{array}{l}\text { Full-time equivalent teachers per } 1000 \text { inhabit- } \\
\text { ants }\left(T_{i}\right)\end{array}$ & 1.205 & 0.474 & 1.327 & 1.191 & -2.259 \\
\hline $\begin{array}{l}\text { Full-time teacher requirement (per } 1000 \text { inhabit- } \\
\text { ants) }\left(F T R_{i}\right)\end{array}$ & 1.543 & 0.350 & 1.347 & 1.565 & 4.978 \\
\hline Literacy content index of local labor market $\left(L C_{i}\right)$ & 0.198 & 0.069 & 0.281 & 0.189 & -11.577 \\
\hline Third-grade exposure $\left(G R_{i}\right)$ & 0.283 & 0.221 & 0.528 & 0.256 & -10.477 \\
\hline Steam engines per 1000 inhabitants (1863) & 0.148 & 0.306 & 0.278 & 0.134 & -3.738 \\
\hline 1(Railroad access as of 1865) & 0.292 & 0.455 & 0.507 & 0.268 & -4.189 \\
\hline Proportion non-Catholic $\left(N C_{i}\right)$ & 0.027 & 0.067 & 0.069 & 0.022 & -5.602 \\
\hline 1(German majority district) & 0.551 & 0.498 & 0.522 & 0.554 & 0.512 \\
\hline 1(Traditional urban center) & 0.100 & 0.301 & 1 & 0 & \\
\hline Average population in 1869 & $20,098.4$ & $25,426.4$ & $42,328.5$ & $17,620.4$ & \\
\hline
\end{tabular}

Based on 688 observations. Unit of observation is the civil subdistrict (Gerichtsbezirk). "Full-time equivalent teachers per 1000 inhabitants" pro-rates half-day and half-year teachers by weighting them at 0.5 relative to a full-time whole-year teacher. Half-day-half-year teachers are weighted at 0.25. Full-time teacher requirement measures how many teachers were supposed to be teaching in a district, according to the law, given the reported number of school-age children. The sample includes 69 districts with traditional urban centers; the remaining 619 are rural

this question. The school census listed every single school (almost 11.000 of them) and provided information on the number of grades, classrooms, teachers, schoolage children and enrolled pupils. We aggregated the data from individual schools into 688 civil subdistricts, used as basic units of reporting in the 1869 population census. The descriptive statistics for relevant variables are reported in Table $3 .^{7}$ As is clear from the average population numbers, the typical rural district was fairly small-some 17-18.000 inhabitants-which reassures us that, in spite of aggregating the school data onto the district level, the dataset will preserve most of the relevant cross-sectional variation.

In order to more accurately capture how much teaching actually took place, we convert the plain totals of available teaching staff into full-time equivalents by weighing half-day teachers and half-year teachers at 0.5 , since many schools responded to overcrowding (i.e., more than 100 pupils per teacher) by splitting their pupils into morning and afternoon groups and teaching each for only half a day. The variable thus created, $T_{i}$, is our measure of the of actual teacher supply in each district. Still, ideally, the law envisioned a full-day, year-round instruction for all school-age children. This regulation together with the law's demand that a teacher be hired for every

\footnotetext{
7 Not all provinces reported a full slate of variables. Galicia, Bukowina and Dalmatia omitted information on grades and classrooms and-more importantly-reported the data aggregated to school districts, which did not correspond very well to the civil districts. For that reason, we had to omit those provinces from our analysis. We also have no data on Hungary.
} 
100 pupils allows us calculate the full-time teacher requirement, denoted $F T R_{i}$, for each district. ${ }^{8}$ In other words, we know for each district not only how many (fulltime equivalent) teachers were actually hired but also how many should have been hired in accordance with the law. The regulation was, of course, exogenous to each district's hiring decisions and so analyzing how the actual teacher supply depended on the teacher requirement can tell us something about the strength of enforcement of the regulation. The third-grade exposure, $G R_{i}$, is the proportion of all school-age children in a district attending a school that had three or more grades. ${ }^{9}$ In line with our exposition in Sect. 3, we use this variable as a proxy for the extent to which local children were exposed to the instruction in Realia and not just the religious content and basic letters taught in the first two grades. We also use the information on the mother tongue of pupils to determine which districts were majority German.

We merged this school dataset with information on industrial and technological development in these districts. Specifically, we use the 1863 empire-wide survey of the use of the steam engine, which we use to calculate our measure of the spread of this technology (steam engines per 1000 inhabitants in each district), and annual data on access to a railroad (K.k. Statistische Zentral-Commission 1864). The latter is a dummy variable, taking on 1 if a district was accessible by railroad by 1865,0 otherwise. They are obviously mere proxies for the level of technological sophistication and the extent of industrialization but they represent some of the most visible and widespread industrial technologies, which could reasonably be expected to call forth a demand for basic literacy and numeracy. At the same time, steam power was a general purpose technology, which could be employed in a wide variety of industries (even agriculture), which makes it a much better proxy for modern technology, broadly speaking, than other industrial technologies which were more sector-specific and would therefore correlate with the degree of this or that district's specialization in a particular sector rather than with the general level of technological development. The relationship between steam technology and human capital has been similarly exploited in the case of France and Great Britain (Lacroix 2018; Diebolt et al. 2017; de Pleijt et al. 2018; Franck and Galor 2017). Similar argument can be made for the railroad.

We supplement these technological measures with an index of the literacy content of the local labor market, $L C_{i}$. The variable is a combination of two pieces of information. The first piece is the local structure of employment, split into 50 occupations (see Table 10 in the "Appendix" for detail). We draw on the data published in the 1869 Cisleithanian census (K.K. Statistische Zentral-Commission 1871). The second piece of information comes from Mitch (1992: 213-214). It is

\footnotetext{
8 The full-time teacher requirement does not just take a district's total number of school-age children and divide it by 100 . Given that we have data on every school individually, we can pay attention to the dispersion of population across the countryside. For example, two village schools of 49 school-age children each will require two full-time teachers. A simple division of an aggregate number by 100 would underestimate the requirement in sparsely populated areas and therefore make them look better supplied than they actually were.

9 Most such schools were full-day all-year schools but where this was not the case, the pupil numbers were prorated. Districts with no third-grade schools at all introduce certain right-censoring into the variable but since they account for only $12 \%$ of the sample, that is unlikely to affect the results significantly.
} 
a classification of occupations by use of literacy for mid-nineteenth-century England. ${ }^{10}$ We make the assumption that the classification is applicable to the Habsburg Empire without major changes, especially since most of the assignments are probably quite uncontroversial. One potentially significant deviation from Mitch (1992) consists in reassigning farmers from the likely category to the ambiguous category, given that Austrian farming was not as advanced and sophisticated as the British one, and we discuss the impact of this adjustment in the next section. ${ }^{11}$ The result is an index between 0 and 1 , where 1 would mean that all jobs in the district required literacy, 0 that none did.

At first sight, it may seem counterintuitive to measure the sophistication of the local labor market in terms of literacy, given the extensive literature indicating that the proportion of literates among adults stagnated and that basic literacy was not particularly in demand during early industrialization, yielding a negligible return (Mitch 1999; Clark 2007: 175-181). These claims are true for literacy per se. Yet, for most of those skills that did bear a return on the labor market, such as reading blueprints, literacy was a stepping-stone from which one progressed further. In this context, Franck and Galor (2017) argue that technological development led to human capital formation including literacy gains. In places with many workers from the "upper tail of the skill distribution," as described by Mokyr (2005), one would obviously find not only higher concentration of practical skills but also higher rates of literacy which those skills presupposed. Our measure, moreover, is not based on reported literacy among the population but approaches the issue from the side of the jobs observed in the various local labor markets.

Table 3 illustrates, among other things, the divide between town and country in matters of schooling by way of a $t$ test. The evidence is consistent with the urban-rural divide apparent in the regulation, as documented in the previous section. The dispersed nature of rural population implied that more teachers were required to staff rural schools. In contrast, urban schools were better able to meet the regulatory requirements. The urban schools were also more sophisticated, as they were more likely to offer a broader curriculum. All these observations of schooling correlate well with the data on the technological and human capital sophistication of the labor

\footnotetext{
${ }^{10}$ Mitch (1992) splits occupations into four groups: those where literacy is indispensable, those where literacy is useful, those where need for literacy is ambiguous and those that did not make use of literacy. The occupations in those four groups are weighted at 1, 0.7, 0.3 and 0 .

11 Our motivation for this reassignment of farmers (that is, farm owners and tenants) is that for several areas we can ascertain that large proportions of them were in fact illiterate. Consider, for example, that according to the 1869 census, farmers amounted to about $40 \%$ of adult male population in Galicia. Further, those who unambiguously required literacy for their jobs (priests, lawyers, teachers, civil servants, etc.) were another $10 \%$. But according to the 1890 census, the first one to cite data on literacy by age and gender for each province, the percentage of Galician men born before 1850 (and therefore adult by 1869), who were literate, reached $18.5 \%$ (although with education creep and lower life expectancy among illiterates, this number likely overestimates the proportion literate, as it would have been in 1869). Noting that $10 \%$ of these $18.5 \%$ must be those with literacy-requiring jobs, that leaves $8.5 \%$ literate men, spread across all other occupations. Even if all these were farmers (which they were not), it would still leave, at a minimum, almost four fifth of farmers, who must have been farming while illiterate. Similar calculation yields about the same fraction of illiterate farmers for Bukowina and Dalmatia. In Istria and Carniola, at least a half of all farmers were illiterate by the same argument.
} 
market: Urban districts were more likely to be connected to the railroad, had more steam engines per capita and reported a higher literacy content index. They also had a slightly higher percentage of non-Catholics. ${ }^{12}$ Our ambition in the next section is to account for this cross-sectional variation, as much as possible, in terms of the interaction between the labor market and the school provision.

\section{The spread of schooling: interaction between labor market and education}

Identifying the interaction between schooling, human capital accumulation and the economy is well known to be fraught with considerable complications. While the older, Mincerian approach linked productivity and earnings (on the microeconomic level) and economic growth (on the macroeconomic level) to educational attainment (measured by years of schooling), recent literature stresses the importance of the quality and effectiveness of schooling (Glewwe et al. 2011; Pritchett 2013). Hanushek (2013: 206), in fact, shows that in regressions explaining economic growth, schooling attainment becomes insignificant once cognitive skill measures (such as PISA test scores in math and science) are included, highlighting the fact that the former actually mismeasures human capital. In addition, the estimation of these relationships is complicated by obvious endogeneity between education provision and economic outcomes (Bils and Klenow 2000). Hanushek and Woessmann (2012) investigate the concurrent issues of endogeneity and mismeasurement through a wide range of econometric approaches (such as IV and difference-in-difference) and types of data (cross-country vs individual-level labor market outcomes) and show that the strong impact of cognitive skill and weak impact of attained years of schooling remains robust across numerous specifications.

Our approach to analyzing the interaction between schooling and economy in nineteenth-century Austria needs to be informed by these recent developments in the field, even though nineteenth-century sources cannot obviously compete with the level of detail and wealth of statistical information on education available today. Thus, while we do not have data on the cognitive skills in math and science for nineteenth-century pupils in the form of standardized international tests, or even the attained years of schooling, we fall back on our close reading of the Austrian regulation of school curriculum to capture the distinction highlighted by Hanushek and Woessmann (2012): Functional literacy and numeracy applied to practical knowledge-the cognitive skills that enhance productivity and lead to growth-were consistently taught only from the third grade onward. In this way, exposure to the third-grade curriculum is the best available proxy for the acquisition of marketable cognitive skills. In contrast, pupils in two-grade schools mostly just attended 6 years of religious indoctrination.

We address the endogeneity issue by modeling district-level schooling provision and its interaction with the labor market in a simultaneous equations framework.

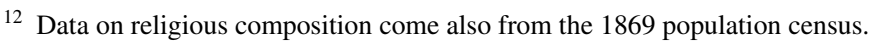


The level of skill and sophistication of the local labor market will presumably be affected by the quality and quantity of local schooling. At the same time, the extent of schooling is a function of the derived demand for education that is informed by the returns to human capital on the local labor market. In contrast to parts of the literature on education and development, which is not primarily concerned with the impact of economy on schooling provision, for us this feedback loop is an important part of our argument: We hypothesize that the pace and the dedication with which primary schooling spreads positively correlates with the schools' effectiveness in imparting practical knowledge to pupils. When such effectiveness is low, the support for schooling among the masses will also be low. Pritchett (2013) cites examples from contemporary developing countries where such dynamic can be observed today.

A simultaneous equations framework allows us to model both of these links explicitly, using a set of three equations. One of them captures the impact of the quality and quantity of schooling on the labor market. The other two equations model the impact of the labor market on the two aspects of schooling. Quantity of schooling is measured by the number of full-time equivalent teachers per 1000 inhabitants $\left(T_{i}\right){ }^{13}$ Our measure of curriculum quality is the third-grade exposure $\left(G R_{i}\right)$. Literacy content index $\left(L C_{i}\right)$ is our labor market measure.

The system of simultaneous equations is specified as follows:

$$
\begin{gathered}
T_{i}=\alpha_{1}+\beta_{1} L C_{i}+\delta_{1} F T R_{i}+\theta_{1} 1_{i}(G)+\mu_{1} 1_{i}(U)+\varepsilon_{i 1} \\
G R_{i}=\alpha_{2}+\beta_{2} L C_{i}+\delta_{2} N C_{i}+\theta_{2} 1_{i}(G)+\mu_{2} 1_{i}(U)+\varepsilon_{i 2} \\
L C_{i}=\alpha_{3}+Y_{i} \gamma_{3}+\delta_{3} G R_{i}+\zeta_{3} T_{i}+\mu_{3} 1_{i}(U)+\varepsilon_{i 3}
\end{gathered}
$$

In Eq. (1a), the quantity of teachers, $T_{i}$, depends on the literacy content index, $L C_{i}$, and on the full-time teacher requirement, $F T R_{i}$. This specification allows for two competing hypotheses, reflecting the contrast between the elites' push from above by way of appropriate legislation and the growth from below motivated by local economic conditions. Under the hypothesis that literacy-intensive labor markets generated strong derived demand for schooling, we should see $T_{i}$ respond to $L C_{i}$ and the coefficient $\beta_{1}$ will be large and significant. On the other hand, if $T_{i}$ was rather driven by the force of regulation, where teachers were appointed by administrative fiat and not in response to market-driven demand, then $T_{i}$ will respond to $F T R_{i}$ which captures the number of teachers desired by the policy-making elites, as implied by the law. In such case, $\delta_{1}$ will be significant and presumably fall somewhere between 0 and 1 , with $\delta_{1}=1$ corresponding to perfect enforcement. Indicator variables $1_{i}(G)$ for a German majority district and $1_{i}(U)$ for a district, containing one or more traditional

\footnotetext{
13 We could also include classrooms per 1000 inhabitants among the endogenous variables in this system of equations, but classrooms and teaching staff are correlated at $\rho=0.98$.
} 
urban center, ${ }^{14}$ are added as controls reflecting the law's stress on socializing pupils into German culture ${ }^{15}$ and its implicit distinction between rural and town schools.

In Eq. (1b), our quality measure, $G R_{i}$, depends again on $L C_{i}$. We expect $\beta_{2}$ to be positive and significant, given our earlier argument that marketable human capital was mostly acquired from the third grade onward. We also include, $N C_{i}$, the proportion of non-Catholics (i.e., Protestants and Jews) in district population, as an exogenous explanatory variable, given the historical association of Protestantism and Judaism with higher demand for literacy (Becker and Woessmann 2009). ${ }^{16}$ The traditional urban dummy and the German dummy capture the effect of the law's presumption that urban schools would be more sophisticated than rural schools and that Germans probably enjoyed higher returns to functional literacy given the amount of useful material published in German relative to other languages of the Empire and so would have a higher demand for it, ceteris paribus.

Finally, Eq. (1c) models the link from schooling to labor market. In addition to $T_{i}$ and $G R_{i}$, the literacy content index, $L C_{i}$, depends on the urban dummy variable and a vector $\boldsymbol{Y}_{\boldsymbol{i}}$ of technological variables, which we take as proxies for the level of technological sophistication and economic advance of the local labor market. These technological variables are the number of steam engines per 1000 inhabitants and a dummy variable for access to railroad by 1865 . We motivate their inclusion by the observation that technological sophistication of the local economy may affect workers' literacy independently of schooling, such as by way of learning on the job through contact with the technologies. If $\gamma_{3}$ turn out large and $\delta_{3}$ and $\zeta_{3}$ small, it will imply that practical skills were primarily acquired on the labor market and not in school.

We sought to anchor the exclusion restrictions that inform our model in the historical context of the issue. Regulation parameters governing the required number of full-time teachers in a district, $F T R_{i}$, had no bearing on the number of grades offered; and they would not presumably affect the local labor market literacy content except

\footnotetext{
${ }^{14}$ Our cutoff for a town is a population of 3000 , and we consider a district urban if it has at least 5000 inhabitants living in such towns. In order to ensure that we capture the traditional market towns, we used the earliest town populations that we could find, which date back to 1843 (Tafeln zu Statistik der Oesterreichischen Monarchie 1843). Thus, we are confident that the urban status is exogenous to the schooling situation in the $1860 \mathrm{~s}$. Other population thresholds for urban status have not affected our estimation results.

${ }^{15}$ Even though the schooling promoted socialization into German culture, there are good grounds for considering $l_{i}(G)$ exogenous to schooling. Most of the districts were either overwhelmingly German or overwhelmingly non-German - there were only 12 non-German districts where the proportion of Germans was above one-third. Thus, it is unlikely that school-induced conversions to Germandom would cause a district to flip from non-German to German; and the ethnic boundaries proved to be stable across time.

${ }^{16}$ Hanushek and Woessmann (2012: 282) count "varying Catholic church histories"- the complement of our variable $N C_{i}$-among exogenous, plausible instruments in regressions involving schooling (or, even more specifically, cognitive skills) and economic development—primarily on account of their longterm persistence from times before education policies got implemented. Such would be our argument also: Austria was obviously a predominantly Catholic country, a consequence of the Habsburg-led Counter-Reformation. The non-Catholic areas that existed in the country were long-standing pockets of secret, undercover Protestantism (and Judaism) that survived the Counter-Reformation but in a very constrained mode, so that it could not really proselytize and thereby change the long-standing religious composition of the country.
} 
through schooling actually supplied. Hence, $F T R_{i}$ does not enter into Eqs. (1b) and (1c). Proportion of non-Catholic, $N C_{i}$, does not feature as determinants of $T_{i}$ in Eq (1a) because non-Catholics had scant reason to support the expansion of a schooling system of Catholic socialization or to sabotage it given that they were exempt from the Catholic religious instruction as long as they could substitute their own from their congregations' own resources (Art. 447). Together with the German dummy, $N C_{i}$ is also excluded from Eq. (1c) on the assumption that cultural correlates of literacy (such as, say, Germandom or Judaism) do not affect $L C_{i}$ except through higher demand for effective schooling, i.e., through $G R_{i}$. In a similar vein, while we include $\boldsymbol{Y}_{i}$, our technological variables, as potential determinants of $L C_{i}$ in Eq. (1c), they do not enter into Eqs. (1a) and (1b) because the derived demand for schooling presumably comes from $L C_{i}$, that is, the more or less literate workers (who may or may not be affected by the technologies they come into contact with) rather than the technologies directly. We also ran Hausman specification tests regarding the potential endogeneity of steam engines and of railroad access but neither of these revealed systematic coefficient differences from our preferred specification $\left(H_{S E}=3.06, H_{R R}=0.57\right.$ where $\left.\chi_{0.95}^{2}(258)=296.5\right)$. This reassures us that it yields consistent estimates. With three endogenous variables and five excluded exogenous shifters, our specification satisfies the order condition. It is easy to verify that the rank condition is also satisfied. All these diverse variables are not strictly contemporaneous (with steam engine data from 1863, schooling data from 1865 and employment data from 1869). But if we can assume that technology, school provision and employment are at least somewhat persistent across time, we can consider them close to contemporaneous. Therefore, we view the identification as coming entirely from cross-sectional variation.

While our dataset is quite detailed geographically, with 688 separate civil subdistricts as units of observation, the inevitable trade-off is that it is also relatively sparse in terms of the number and range of variables that are available at local level. For example, a preferred measure of human capital return or of skill premium would be the ratio of skilled and unskilled wage. Such statistic may be available on the level of the province but not for each district. Consequently, we need to rely on close proxies, such as the literacy content index, $L C_{i}$. In addition, the lack of a greater number of potentially useful variables makes the model perhaps too "bare-bones" and therefore at risk of bias due to omitted variables. We counter this risk through local fixed effects. On the most aggregate level, our dataset contains school districts across eleven provinces, so our base specification includes ten province-level fixed effects. For a finer account of local variation, we rely on lower-level units: In the administrative system of Imperial Austria, groups of two to five civil subdistricts (our unit of observations) combined to form political districts which formed the lowest level of political administration. There were 258 of them. We therefore include in the model 257 political district fixed effects, which capture the impact of districtspecific idiosyncratic factors and thus somewhat mitigate potential selection problems driven by unobservables. As a result, the identification comes from variation within those political districts.

The results are presented in Table 4. Columns (i)-(iii) show the estimates with province-level fixed effects, columns (iv)-(vi) estimates with district-level fixed effects. The coefficients in these two specifications are structurally quite similar, so 


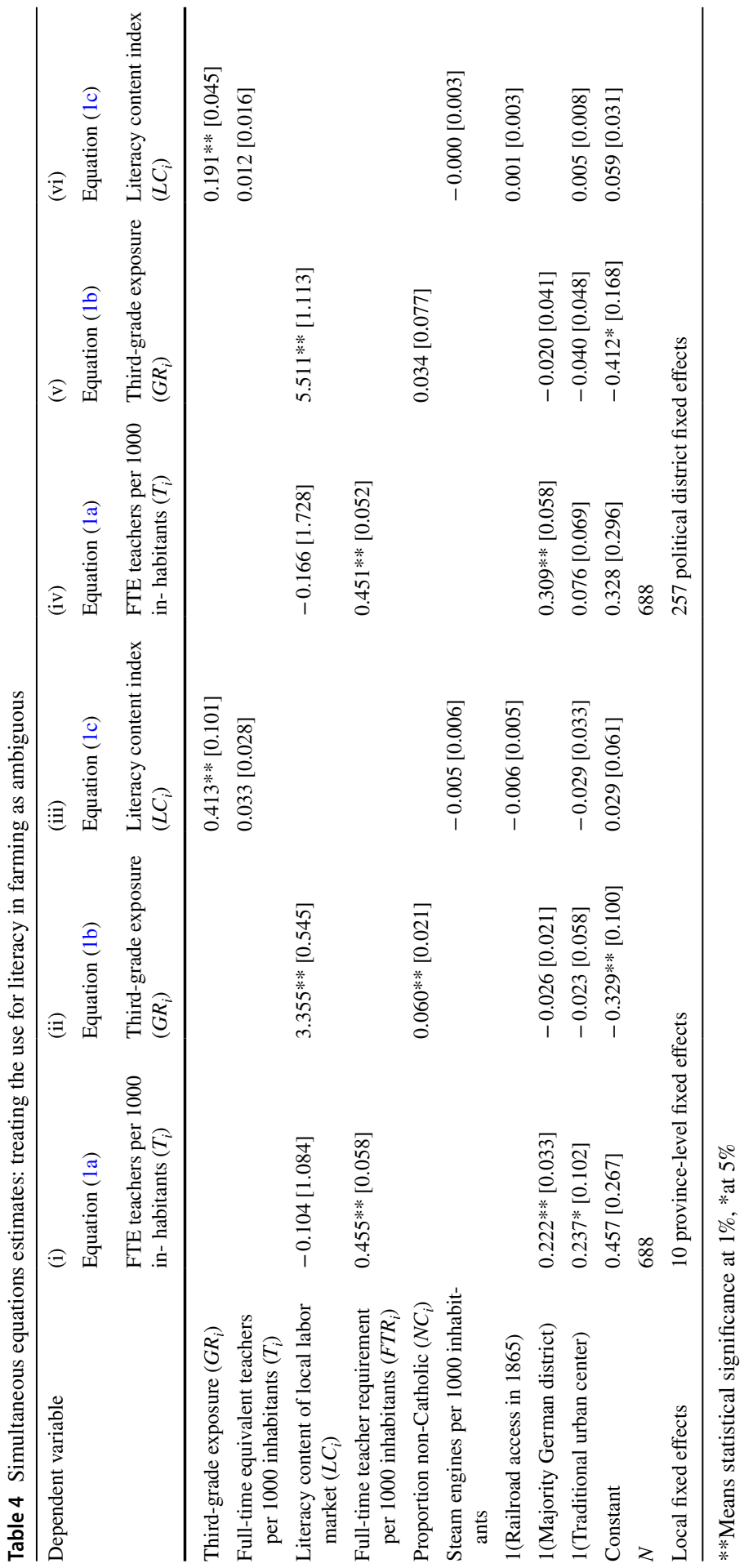


our discussion focuses on the results based on the finer geographic controls, in columns (iv)-(iv). Coefficients in Eq. (1a) show that the diffusion and extent of elementary schooling was driven primarily by the enforcement of the regulations rather than derived demand for marketable human capital. The coefficient on $L C_{i}$ is not only of the "wrong" sign and statistically insignificant, it is also tiny: Combined with s.e. $\left(L C_{i}\right)=0.069$, the local labor market literacy content would not make an appreciable impact on district teaching staff, even if the coefficient were ten times as large. On the other hand, with $\delta_{1}=0.451$ the impact of $F T R_{i}$ was sizeable. For every full-time teacher required by the law, a district hired on average 0.451 teachers, or not quite one half-day teacher. This coefficient is statistically different not only from 0 but also from 1: The regulation was far from being translated into reality at one-to-one. A negligible $\beta_{1}$ and positive $\delta_{1}$ together imply that the policy-making elites forced, through regulation, more schooling on the people than the people thought worth it.

In Eq. (1b), however, the link between schooling and local labor market is strong. Exposure to third- and higher-grade curriculum $\left(G R_{i}\right)$ strongly responded to $L C_{i}$, so that increasing the explanatory variable by one standard deviation $(0.069)$ was associated with extra $38 \%$ school-age children attending a three-grade school, which is almost twice the size of s.d. $\left(G R_{i}\right)=0.22$. So, when literacy played a significant role in the local labor market, it also generated strong demand for third-grade curriculum (while it played little to no role in determining where a school would be established as per Eq. 1a). This stark contrast between insignificant $\beta_{1}$ and large $\beta_{2}$ is consistent with our reading of the law that practical, marketable skills were only taught from third grade on, while the lower two grades generated little in return-bearing human capital in pupils.

Finally, in Eq. (1c) we observe the impact that schooling had on the labor market. Starting from the least impactful variables, the technological variables do not record any sizeable effect, which suggests that the useful human capital was not acquired when workers encountered new technologies on the job. Clearly, what mattered were the schools - but not whether a district had enough schools and teachers but rather what kind of schools it had. The impact of $T_{i}$ is quite small $\left(\zeta_{3} \times\right.$ s.d. $\left(T_{i}\right)=0.012 \times 0$. $474=0.006)$ while that of third-grade exposure is appreciable $\left(\delta_{3} \times\right.$ s.d. $\left(G R_{i}\right)=0.19$ $1 \times 0.221=0.042$ ). An increase in literacy content index by 0.042 , given the way we have constructed it, is equivalent to about $6 \%$ local workers progressing from occupations where the use of literacy was ambiguous to jobs where it was indispensable. Note that this negligible impact of rudimentary schooling, represented by $T_{i}$, once exposure to the more advanced third-grade curriculum, $G R_{i}$, is introduced, mirrors the results reported, for example, in Hanushek (2013): It is not schooling per se that enhances productivity and growth, it is schooling that imparts something practical and functional that generates a positive return.

In Table 5, the specification and data are the same as in Table 4, except for a different classification of farming with respect to the use of literacy, as the table titles indicate. As we mentioned at the end of Sect. 4, our assignment of farming to the "ambiguous" category deviates from Mitch's (1992) classification. Table 5 shows how sensitive our results are to this change. Columns (i)-(iii) in both tables do not exhibit much difference, whether in terms of size of coefficients or significance. The exception is the coefficient on third-grade exposure in Eq. (1c), which becomes smaller and insignificant. In columns (iv)-(vi), the change does not affect the results in Eq. (1a) 


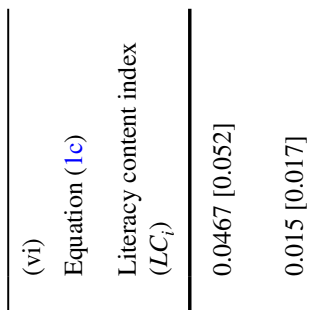

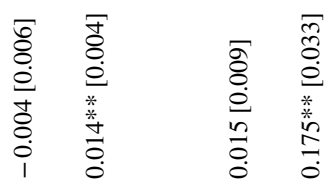

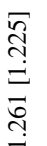

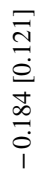

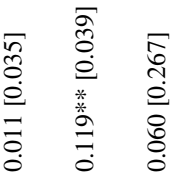

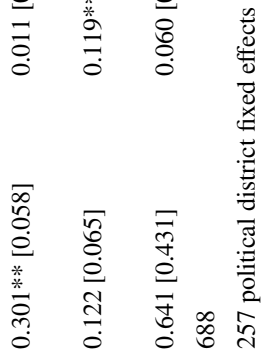

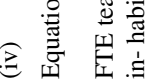

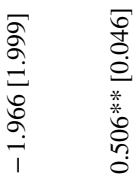

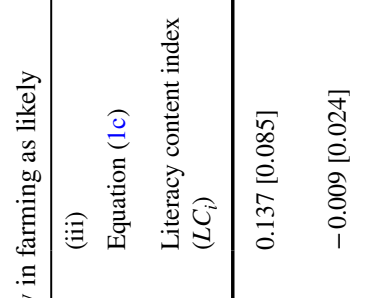

$\begin{array}{llll}\kappa & 0 & & \pi \\ \delta & 0 & 0 & 0 \\ 0 & 0 & 0 & 0 \\ 0 & 0 & 0 & * \\ 0 & 0 & 0 & 0 \\ 0 & 0 & 0 & 0 \\ 0 & 0 & 0 & 0\end{array}$

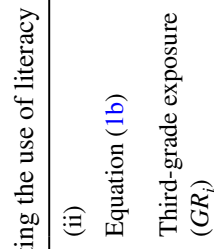

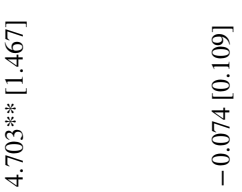

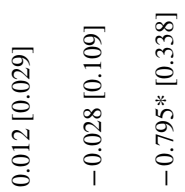

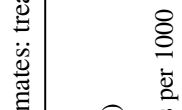

可<smiles>[13CH]</smiles>

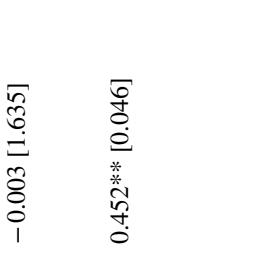

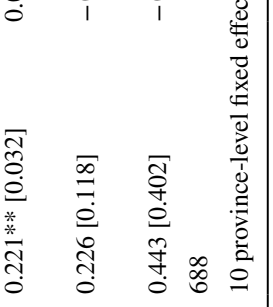

$\Leftrightarrow$ 疍

$\frac{\substack{1 \\ 0}}{0}$

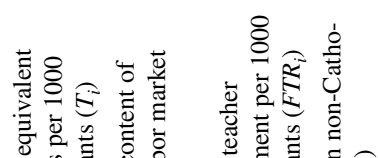

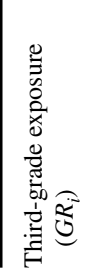

§

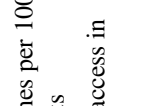

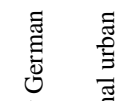


and in the other two equations the coefficients have the same signs and order of magnitude but their values go down and lose significance also. The reason is that reclassifying farming as likely a literate job increases the measured sophistication of the labor markets in rural districts and makes the difference between country and city on this score appear smaller. ${ }^{17}$ Consequently, a larger part of the urban-rural difference that in Table 4 is captured by the educational variables is in Table 5 accounted for by the urban dummy, especially in Eq. (1b). The contrast between the two tables shows that, once the 257 district-level fixed effects are included, the estimation is somewhat sensitive to measurement of literacy content but, for reasons that we have given at the end of Sect. 4, we consider coding literacy in farming as ambiguous a more accurate reflection of the historical reality of Austria of 1860s and for that reason see the results in columns (iv)-(vi) of Table 4 as the better estimate.

Considering these results, how conducive to economic development was the Austrian schooling system as a whole then? The third-grade curriculum clearly could make a difference to the level of sophistication on the local labor market. But as of 1865 , two-thirds of all pupils (three quarters in the countryside) attended only twograde schools. This severely limited the contribution that Austrian primary schools could make. Moreover, the coefficients from columns (v) and (vi) in Table 4 suggest a potential divergence between high-skill and low-skill districts, ending with an under-education trap for the latter. High-literacy labor markets encouraged expansion of the curriculum beyond the second grade, which further enhanced the sophistication of the local labor force. A virtuous cycle of sorts could develop. On the other hand, districts with low $G R_{i}$ and $L C_{i}$ would tend to stay low. (Note that other variables in these equations do not offer much opportunity to exogenously push a low-skill district onto a path of human capital development.) Such interpretation is consistent with some anecdotal historical evidence: Frank (1898a: 17) relates the widespread introduction of third-grade curriculum in many towns during the boom of the 1850s, while the countryside remained very lukewarm about any such extension (Cvrcek and Zajicek 2018). One might therefore somewhat cynically conclude that the elites' original plan succeeded: The schooling system kept the peasants pliant while conceding to the towns the necessary means for at least some accumulation of useful human capital.

\section{Interaction of school provision and local politics}

For one of the provinces, Lower Austria, we are able to look at school decisions at an even finer detail, by considering determinants of the changing supply of teachers and classrooms in individual schools. This will allow us to look at where the financial support for schools came from. We matched the 1865 school census with a teacher directory published in 1852 (containing information as of Autumn 1851),

\footnotetext{
17 It also produces certain unusual outcomes: For example, it makes the Istrian district of Castelnuovo, where over $90 \%$ of the workforce was still in agriculture in 1869 , a more sophisticated labor market than the industrialized and urbanized districts of North Bohemia, with two-thirds in industrial employment.
} 
Table 6 Means and standard deviations for schools in Lower Austria

\begin{tabular}{|c|c|c|c|}
\hline & 1851 & 1865 & $H_{0}: X_{1865}=X_{1851}$ \\
\hline Classrooms per school & $\begin{array}{c}1.299 \\
{[0.761]}\end{array}$ & $\begin{array}{c}1.402 \\
{[0.837]}\end{array}$ & $\begin{array}{c}t=6.72 \\
p \text {-value }=0.000\end{array}$ \\
\hline Teachers per school & $\begin{array}{l}1.552 \\
{[1.027]}\end{array}$ & $\begin{array}{c}1.577 \\
{[1.039]}\end{array}$ & $\begin{array}{c}\mathrm{t}=1.121 \\
\mathrm{p} \text {-value }=0.263\end{array}$ \\
\hline Pupils per school & $\begin{array}{l}135.65 \\
{[99.14]}\end{array}$ & $\begin{array}{l}131.93 \\
{[97.87]}\end{array}$ & $\begin{array}{c}\mathrm{t}=-3.02 \\
\mathrm{p} \text {-value }=0.003\end{array}$ \\
\hline Pupils per classroom & $\begin{array}{l}105.87 \\
{[51.73]}\end{array}$ & $\begin{array}{c}94.88 \\
{[41.25]}\end{array}$ & $\begin{array}{c}\mathrm{t}=-8.59 \\
\mathrm{p} \text {-value }=0.000\end{array}$ \\
\hline Pupils per teacher & $\begin{array}{l}90.49 \\
441.21]\end{array}$ & $\begin{array}{c}85.89 \\
{[36.87]}\end{array}$ & $\begin{array}{c}\mathrm{t}=-3.83 \\
\mathrm{p} \text {-value }=0.000\end{array}$ \\
\hline 1(classroom expansion) & \multicolumn{2}{|c|}{$\begin{array}{c}0.112 \\
{[0.315]}\end{array}$} & \\
\hline 1(new teacher hired) & \multicolumn{2}{|c|}{$\begin{array}{c}0.142 \\
{[0.349]}\end{array}$} & \\
\hline $\begin{array}{l}\text { Growth in pupils (ratio of } 1865 \\
\text { pupils to } 1851 \text { pupils) }\end{array}$ & \multicolumn{2}{|c|}{$\begin{array}{c}0.996 \\
{[0.281]}\end{array}$} & \\
\hline $\begin{array}{l}\text { Change in steam power in HP } \\
\text { between } 1851 \text { and } 1863\end{array}$ & \multicolumn{2}{|c|}{$\begin{array}{c}3.222 \\
{[15.264]}\end{array}$} & \\
\hline 1(urban location) & \multicolumn{2}{|c|}{$\begin{array}{c}0.074 \\
{[0.262]}\end{array}$} & \\
\hline Number of observations (schools) & \multicolumn{2}{|c|}{1013} & \\
\hline Number of school/church districts & \multicolumn{2}{|c|}{45} & \\
\hline Number of civil districts & \multicolumn{2}{|c|}{70} & \\
\hline
\end{tabular}

By "urban location" we mean schools in towns with more than 2000 inhabitants as of the 1857 population census. "Change in steam power" is the change, between 1851 and 1865, in the total horse power embedded in steam engines employed in each school's village

which includes information not only about each individual teacher in the province but also data about the schools where they served (Kaiser 1852). As a result, we know, for each school, how many classrooms, teachers and pupils it had in both years and, most importantly, from the 1852 source we know the school patron.

There were 1143 schools in Lower Austria in 1865. Of those, we do not use the 91 Viennese schools, which were all run by the city council and obviously unrepresentative of the usual country school. Another 29 schools were excluded because they were new in 1865 and less than 14 years in operation, lacking the 1851 data. Of the remaining 1023 schools, we successfully matched 1013 across the two periods. ${ }^{18}$ There were a few cases where the school record was incomplete but even excluding those, we have, outside Vienna, a near-complete universe of all Lower-Austrian schools.

Table 6 shows the descriptive statistics for this one-province dataset. Most of the schools were small, with one classroom and one teacher, although a non-negligible portion also had a teaching assistant. The ratio of 1865 enrollment to 1851 enrollment, with a mean of 0.996 , shows that overall the pupil population was fairly stable. "Change in steam power" is our measure of technological change on the local

18 In addition, there were also 22 schools extant in 1852 but defunct by 1865 for which we do not have the 1865 data. 
level (K.k. Statistische Zentral-Commission 1852, 1864). ${ }^{19}$ No other economic statistics were consistently available at the level of individual villages, except for the location and size of steam engines for 1852 and 1863 . We take the difference in total locally employed horsepower embedded in local steam engines as a proxy for the pace of technological change and therefore changing technological sophistication. The indicator variable for urban location takes on 1 for all schools located in localities that, as of the 1857 census, had at least 2000 inhabitants.

The t-tests in Table 6 show a systematic difference in most of the school characteristics across the 14 years but practically, the changes were mostly quite small. Values for pupils per teacher and pupils per classroom indicate that Lower Austria made some progress toward greater compliance with official regulation but it was modest progress. Table 7 , in fact, provides a more detailed picture on this score while also splitting the schools by type of school patron. Looking only at classrooms and teachers per 1000 pupils alone, one could have concluded that Lower Austria by and large was on the right side of the law. But when we use data for individual schools to calculate the proportions of compliant schools, the picture is far grimmer, especially in terms of classrooms. The last two columns show the proportion of schools that hit the government target of fewer than 100 pupils per classroom and per teacher and enjoying full-day education for the whole year: In this one of the most advanced provinces with a near-complete network of primary schools, only about one-fifth (in 1851) and one quarter (in 1865) of schools fully cleared the regulation bar. The table yields only ambiguous evidence on which type of patron was most supportive to schooling provision: Municipal patronage correlated with high availability of classrooms and staff but the instruction was apparently not sustained for a full day, all year long (perhaps the classrooms were too small?). Feudal lords, on the other hand, supported schools with lower levels of provisions but they oversaw some of the fastest improvements in compliance over the fourteen-year period.

The detailed information on school patronage is relevant to the debate on the role of entrenched landed interest in provision of schooling. In cases of countries with non-democratic politics, where election participation and results do not exist, the frequently posited statistical relationship between land access inequality and school provision usually leaves the actual political process around school financing unspecified-a black box hiding the implicit assumption that where there was a political will (to obstruct), the landed interests could find the way. With our information on school patrons and the law's specific stipulations about how schools should be financed, we can get a much better, closer look at who negotiated with whom and which financing items were at stake.

As mentioned above, school patrons-usually the local landowners-were saddled with paying for maintenance and contributing to physical expansion of schools. After 1848, the last remnants of feudal administration were abolished and just as peasants were now freed from forced labor, the aristocrats, too, expected to be freed from the burdens of feudal public administration. This indeed came to pass in many respects but in case of school patronage, the legislative adjustment was piecemeal.

\footnotetext{
19 Note that we excluded steam engines as a determinant of schooling supply in Sect. 4 on the grounds that its effect operates through its impact on local human capital. But since we cannot calculate the literacy content index for individual Lower-Austrian villages (lacking sufficiently detailed data), we include a steam power among explanatory variables here.
} 


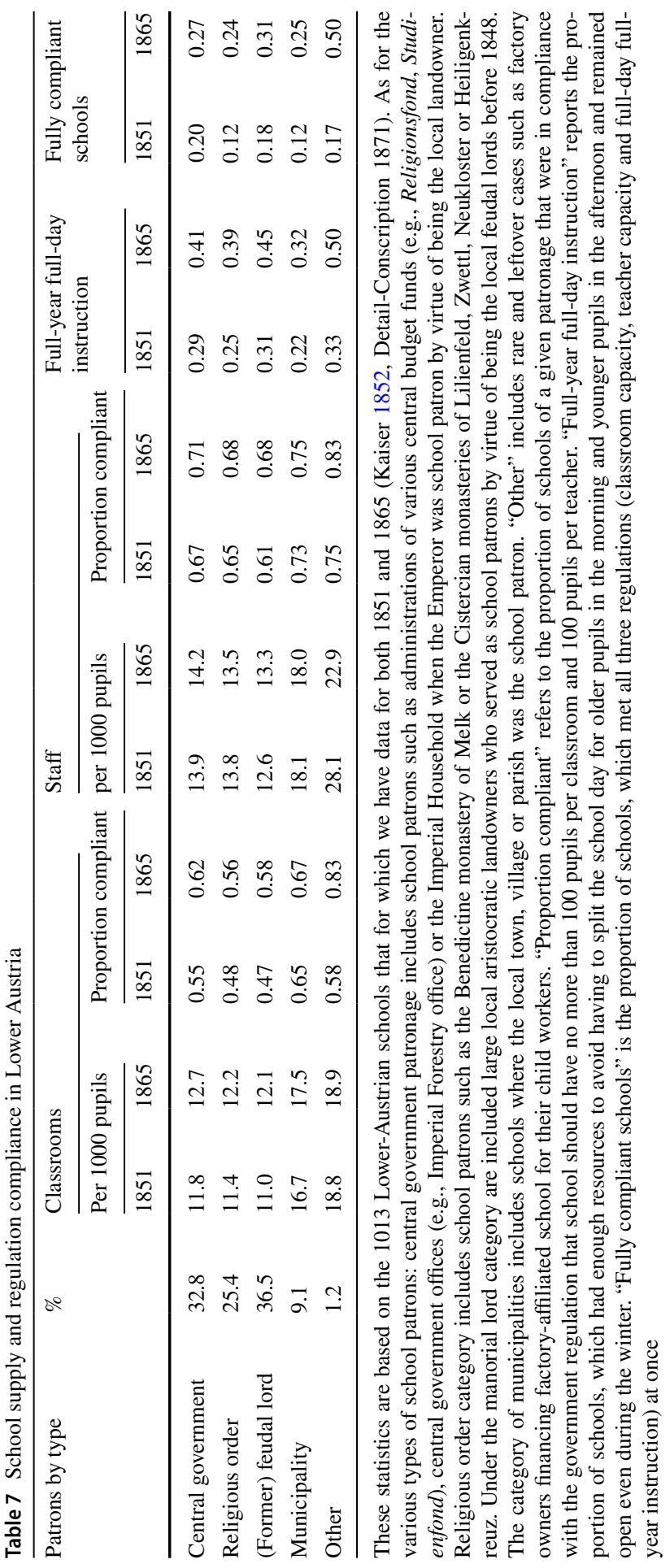


Specifically, in 1849, the ministry of education declared that patrons were still expected and obliged to pay for maintenance but that the cost of school expansion was subject to voluntary mutual understanding with other school-financing parties (primarily the municipalities which now inherited many of the public duties previously performed by aristocratic landlords); should such understanding fail to materialize, all large-scale works were to be currently suspended (Helfert 1860, 140). This was a temporary fix, and the declaration promised a new, thorough legislative treatment of school financing in short order. But no such new legislation was passed until the liberal reforms of 1869 , with the exception of outright abolition of the school patronage-in Lower Austria in April 1864. This "temporary" institutional framework of the years 1849-1864 gives us an opportunity to look more closely at which social groups and political constituencies were the likely supporters or obstructors of schools. We use our Lower-Austrian data on classrooms and teachers in the years 1851 and 1865 to see how likely an extra classroom was built and an extra teacher hired, conditional on the number of pupils and type of school patron, who differed from each other in their preferences. For classroom expansion, our specification is:

$$
\begin{aligned}
& P(1(\exp )=1 \mid X) \\
& =\Phi\left(\alpha+\sum_{i=1}^{4} \beta_{i} 1\left(\text { Patron }_{i}\right)+\beta_{5} 1(\text { urban })+\beta_{6} 1(\text { noncompliant })+\beta_{7} 1(\text { urban })\right. \\
& \left.\times 1 \text { (noncompliant })+\beta_{8} \text { ppc } 51+\beta_{9} \text { growth }+\beta_{10} \Delta H P\right)
\end{aligned}
$$

where 1(exp) is an indicator of classroom expansion, taking on 1 if a new classroom were built between 1851 and 1865, 1( (Patron $_{i}$ ) are indicator variables for four different types of patrons (leaving the fifth, central government, as the omitted category), 1 (urban) is an urban dummy, 1(non-compliant) is an indicator of non-compliance with regulation in 1851, taking on 1 when the number of pupils per classroom in 1851 was above 100 , and 0 otherwise, ppc51 is the actual number of pupils per classroom in 1851, growth is the ratio of pupils in 1865 to pupils in 1851 , and $\Delta H P$ is the change in local steam engine horsepower between 1851 and 1863 . We estimate analogous model for staff expansion where ppc51 is replaced with ppt51, or pupils per teacher in 1851, and non-compliance is defined with respect to the teacher regulation but all other variables are the same.

We can formulate alternative hypotheses about the patrons' behavior, depending on the underlying theory. If the "obstructionist elites vs popular demand" explanation is correct, we expect the schools of central government patronage to expand only when they are overcrowded (by regulation standards) but not otherwise, the schools of feudal patronage to expand rarely (even when overcrowded) due to elite resistance and the schools of local municipal patronage to expand often (possibly even when NOT overcrowded) but certainly not less than schools of other patronage. Why? The central authorities presumably expressed their preferences in their school regulations and so in the $32.8 \%$ of schools where central government was the school patron, they would be guided primarily by the parameters laid down there. The landed interests- the former feudal lords, still stuck with the residual patronage obligations-now had a stronger hand in blocking school expansion (if they were so inclined) since their contribution to 
fixed costs of construction was voluntary, while their continuing obligation to pay for maintenance of all school premises (even if school expansion were built on someone else's dime) gave them an incentive to veto the expansion. When the municipalities acted as school patrons, they had to pay for new construction out of their own pocket (while also financing teacher salaries), but since this confluence of salary, maintenance and all other obligations under one roof made them the sole stakeholders, they were also able to avoid potentially difficult negotiations with other parties. If landed opposition to broad taxation for school purposes was the main constraint, then municipal patronage, unhindered by this opposition, should have had more success in raising resources for the expansion. In fact, if there were a truly strong popular demand for schooling, municipal patronage could be expected to expand schools faster not only relative to feudal patronage but even compared to government patronage where expansion presumably stopped once regulations were satisfied. ${ }^{20}$

An alternative hypothesis would be that the opposition to schools did not come from the landed elites but from other strata, such as the general population. We saw in Sect. 5 that economic impact of schooling was likely weak, and in Sect. 3 that the conservative ideological motivation behind the curriculum was strong, so there are grounds for expecting the conservative elements (such as the landed elites and a monarchical government) to have some stake in such schooling system. If that were the case, i.e., if feudal lords and central government made a financial difference in support of it, we would expect the municipally financed schools to be the least likely to expand because they had to carry the cost of expansion themselves whereas other communities had outside contribution from their patron. This hypothesis turns, to some extent, on the content, i.e., practical economic usefulness of the education, which was fully under the control of the central government. The only variation in content that the regulation allowed was in the number of grades taught: Country schools were mostly expected to teach only two grades, while urban schools could add a third and sometimes even a fourth grade. Both past (Frank 1898b: 62) and modern analysts (Engelbrecht 1986: 230) agree that towns seized on this option, thereby opening a gap between urban and rural schools. Since we only have grades data for 1865 , we cannot model expansion of content across time but we can proxy for the difference by separating rural and urban communities using the dummy variable 1(urban). In 1865, some 75 schools out of 1013 were urban schools by our definition of a town and they offered 3.01 grades on average, whereas the remaining 938 country schools taught an average of 2.26 grades $(t=12.6, p$ value $=0.00)$. The skills taught in higher grades, potentially useful in crafts or entry-level clerk jobs, could, we assume, incentivize towns and cities to invest more in their schools relative to their rural counterparts.

Table 8 reports the coefficients and the marginal effects from the probit estimation for classroom expansion. For comparison, we also include results from a linear probability model (LPM), estimated by way of a simple OLS: It is straightforward to see that the two models yield structurally similar results. Our main model is reported in column (iii), while column (i) shows the same specification without the fixed effects for civil and church (or school) districts. Note from the difference in number

\footnotetext{
${ }^{20}$ The preferences of religious orders are not clear a priori but they were a large, clearly defined group so we use them as an additional, separate control.
} 


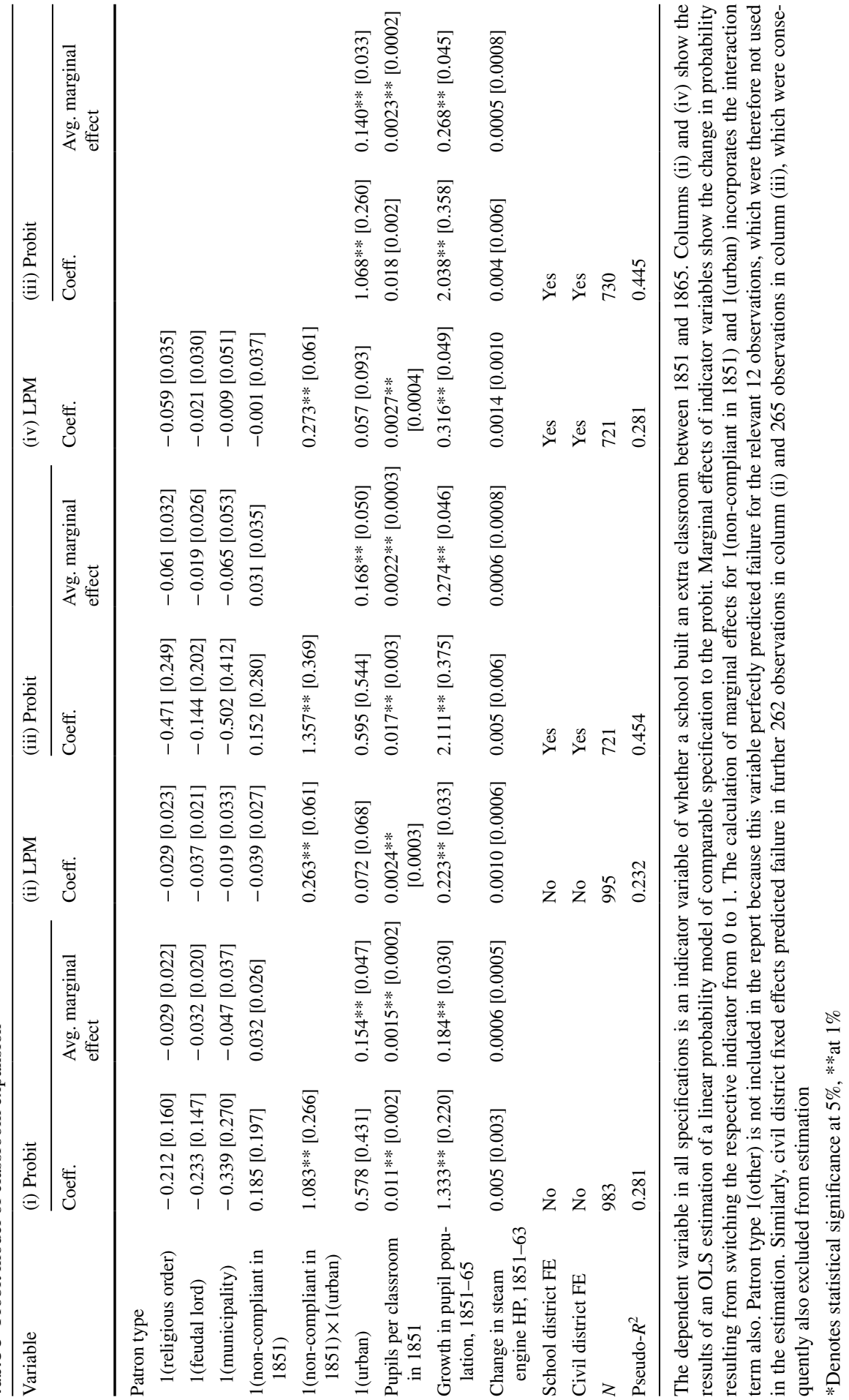


of observations in the two models that the district dummies perfectly predicted failure (to expand) for 262 schools, or about a quarter. As a result, in the estimation sample of 721 schools, some $15.5 \%$ actually built new classrooms, as opposed to $11.2 \%$ in the overall sample. Most of the effects have signs and sizes that are intuitive and realistic. For example, the marginal effect on pupils per classroom implies that for every 5 pupils, the probability of building a new classroom increased by $1 \%$. Similarly, a 10\% increase in pupil population between 1851 and 1865 increased that probability by about $2.74 \%$. The change in steam power had a weak impact: An increase by one standard deviation (15.3HP) would raise the probability by $0.9 \%$. But the institutional variables are the most interesting. The coefficients and marginal effects on patron types indicate that having the central government for a patron (the omitted category) was most conducive for a classroom expansion: All patron dummy variables have a negative impact—not a large one but not a negligible one either. For example, a school of municipal patronage was $6.5 \%$ less likely to build a new classroom than a school of central government patronage. In a sample, where $15.5 \%$ of all schools built a new classroom over the period, that is a noticeable difference. Importantly, the feudal patronage had the smallest negative impact. There also appears a big difference between urban and rural schools but it is particularly strong when a school was in violation of the classroom regulation: An urban school that was non-compliant in 1851 was on average $22.5 \%$ more likely to build an extra classroom by 1865 compared to its non-compliant rural counterpart. The enforcement was clearly weaker in the countryside, with the mean marginal impact of non-compliance equal to 0.019 , compared to 0.157 for urban schools. These results are more clearly visible in Fig. 1, which contains the imputed probability

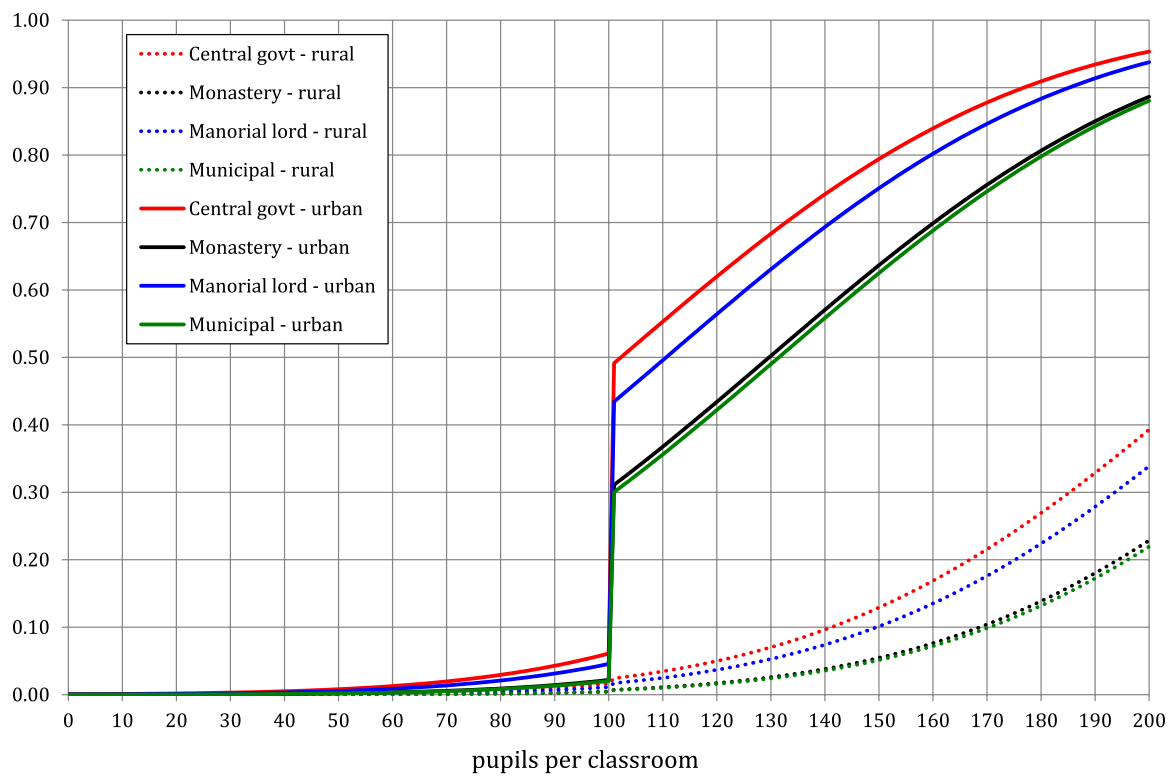

Fig. 1 Imputed probability of classroom expansion by type of school patron 
of classroom expansion for schools in various institutional settings and which highlights the impact of regulation enforcement in towns and cities: The marginal impact of the 101st pupil in a classroom reached $43.1 \%$ for urban schools under central government patronage and $28.0 \%$ for urban schools under municipal patronage. Contrast that with the almost toothless enforcement in the countryside (less than a $1 \%$ increase in probability of expansion at the crossing of the regulation threshold). There, the central government's best chance of increasing the school supply was not to send a circular citing its regulation but to send the money in its role of the school patron.

The overall pattern is quite similar in Table 9 and Fig. 2, which report the result of a comparable probit model for teaching staff expansion, where the dependent variable is 1 if the number of local teachers increased between 1851 and 1865. As in the case of classrooms, the teacher supply, too, responded predictably to the number of pupils per teacher and their growth; the steam power proved unimportant as a determinant and the schools of municipal patronage were the least likely to hire more staff relative to schools under other patronage. But with staff, we cannot blame patronage directly, for patrons had no responsibility regarding staff outlays. The impact was indirect: Patron municipalities, saddled with the financial costs of both kinds of expansion, were apparently less likely, other things held equal, to undertake either. Together, the results in Tables 8 and 9 suggest that the type of school patron did matter and that non-municipal patronage, as a source of "outside money," made a tangible financial difference. The central government was the most generous school patron, followed by the feudal lords. It is hard to square this evidence with the notion that the landed elites were the main obstacle to school expansion. It is even harder to interpret it as indicating a grassroots support for expansion of schooling along the extensive margin: The schools of municipal patronage, where the local population was most completely in control of the local school supply, expanded most reluctantly. If the main hindrance to school expansion had been the landed elites' veto (as opposed to scarcity of resources), the schools that were free of it should have flourished most. Even in urban areas, where one might expect the dynamism of modern economic sectors to generate some popular demand, the estimation offers more support for the large role played by the vigorous enforcement of government regulation, i.e., prodding from above rather than a push from below.

One final result should not get lost in the school patron analysis. The legally stipulated 100-pupil benchmark was far from ideal for effective education, as was recognized even by contemporaries. Yet, for both classrooms and staff, expansion was highly unlikely across the board once schools got on the right side of the regulation. ${ }^{21}$ The rarity of expansion in regulation-compliant schools-the fact that even

\footnotetext{
21 Rural schools were unlikely to expand even when they were on the wrong side of it, unless the number of pupils per classroom rose quite far above 100 . They were more likely to teach half-days and only when even those arrangements strained the capacity did they opt for expansion.
} 


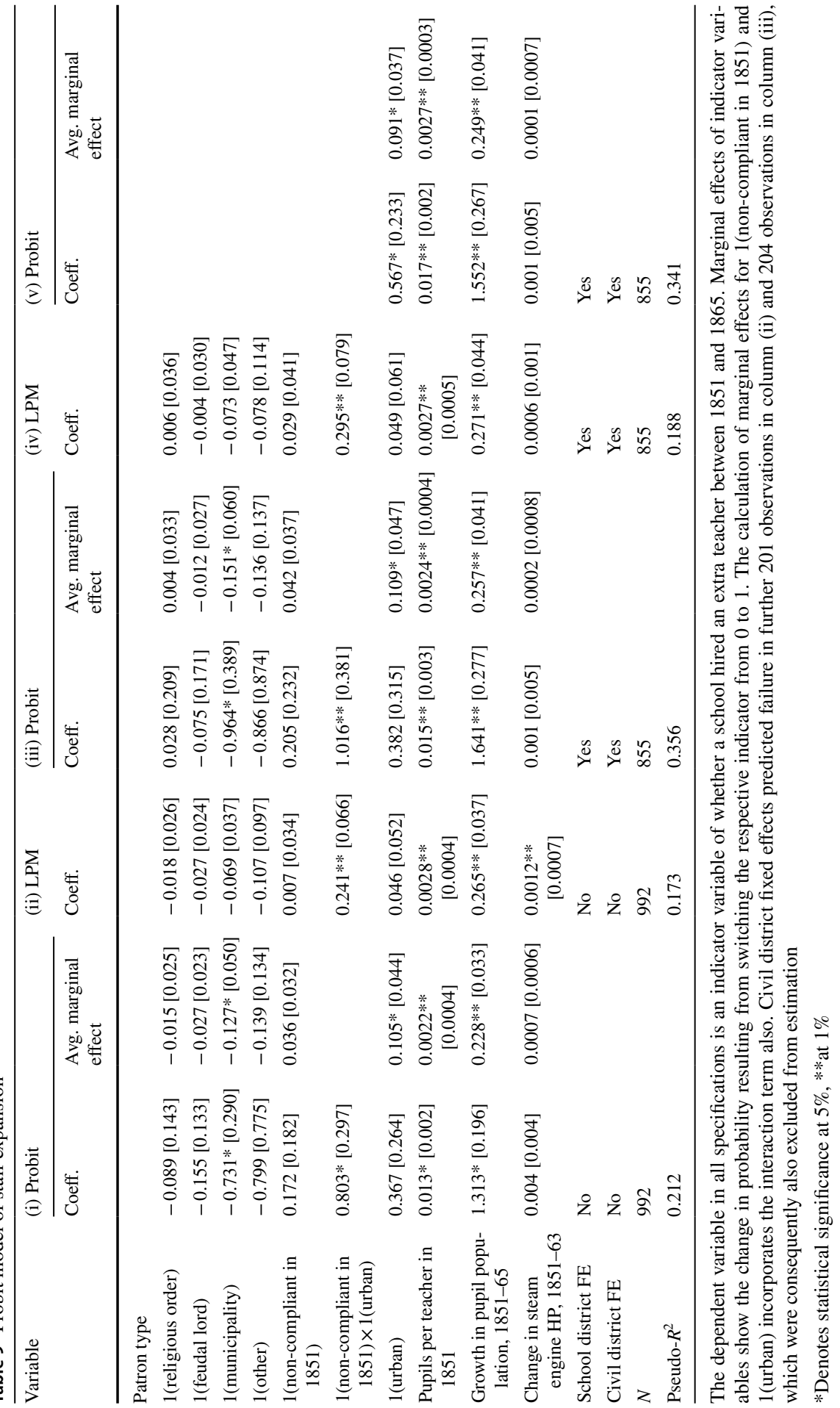




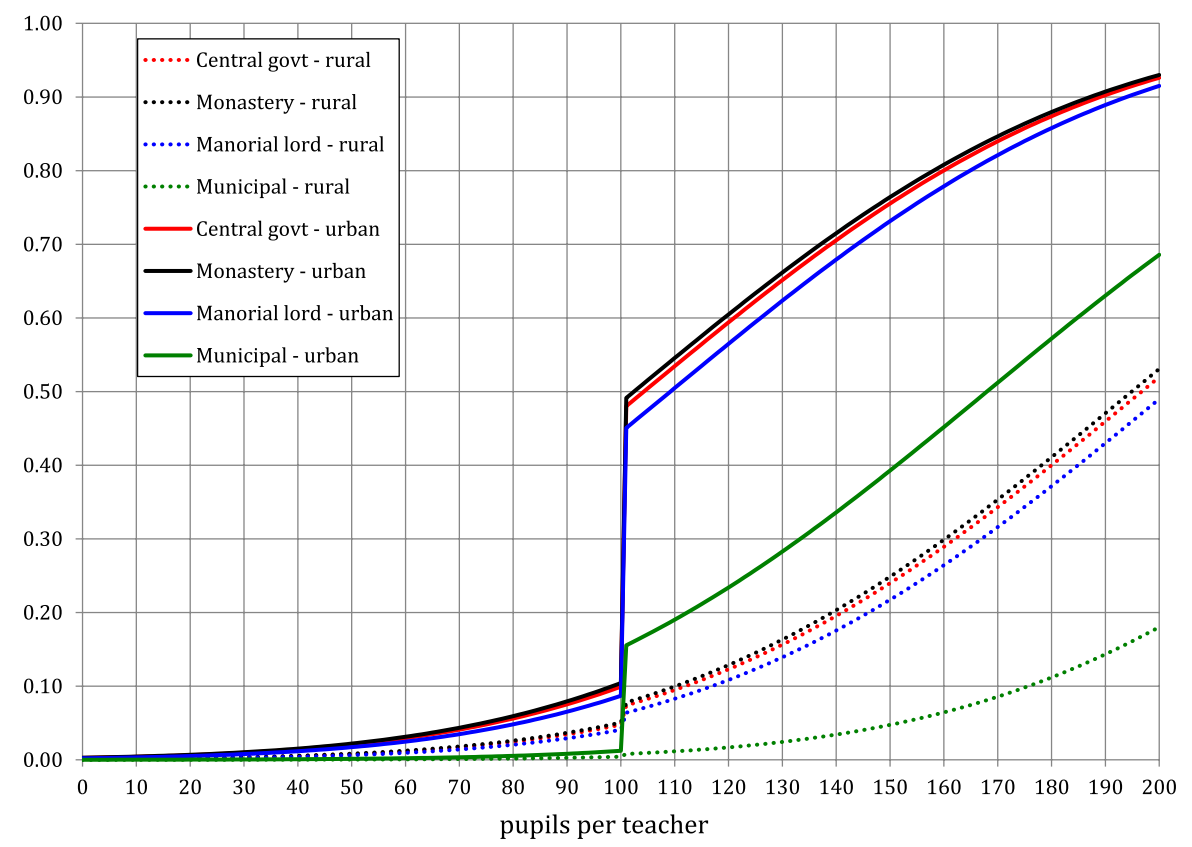

Fig. 2 Imputed probability of staff expansion by type of school patron

the central government, the most avid patron, looked at best to just make good on its own regulation (especially in towns) but go no further-suggests that the kind of schooling on offer in Austria was not particularly desired or loved by anyone. Even in that context of general apathy, however, the landed interests do not deserve the bad press they usually get—not in the Austrian case, anyway. In column (v) of Tables 8 and 9, we present our estimates of the same models, this time stripped of all the regulatory and patron-related variables. The coefficients and marginal effects of the remaining variables are structurally similar to columns (i) and (iii) but note that, seizing on the large marginal effect of the urban dummy, one could easily reinterpret these results as showing that the modernizing, industrializing cities were expanding and staffing their schools fast while the countryside, the power base of the landed elites, lagged behind. The aristocrats can make for easy scapegoats, and it takes the detailed analysis of the local, school-specific information on patrons (together with a description of the institutional framework of school financing) to show that the situation was in fact different. Without such analysis and such information, one could easily reach the more prevalent conclusion of "Tory opposition." 


\section{Conclusions}

The analysis reveals several important features of the Habsburg educational system. Firstly, any evidence of a positive effect of this schooling policy on economic development we find is limited to instruction in practical subjects from third grade on, which was denied to an overwhelming majority of the population. On some level, this is not surprising because economic advance was never the main aim of the schooling system the Habsburg government was trying to put together. Secondly, we find next to no support for the notion that the prospect of economic development generated a strong derived demand for the public education the Habsburg rulers were offering - again, with a caveat applying to higher grades. Apparently, the Viennese government designed a flawed product, decreed that it be oversupplied and burdened local communities with paying for it. We have no estimate of how much deadweight loss this policy generated but given that the government imposed more schooling than was demanded by the general population, one may expect that there must have been some. Thirdly, we also find little evidence to suggest that the landed elites were the main political bulwark against the spread of primary schooling, as is often argued. After all, the system was designed to yield them a political dividend. But it was also granted partially as a concession to changing times. Consequently, they were not enthusiastic supporters of it but they carried out their assigned duties within the institutional framework and they did it to somewhat greater extent than some other types of school patrons.

Overall, this adds up to a different picture to that painted regarding the modern rise of public education. While all the elements of the usual story-the industrialization, the public provision of schools, the political voice of important pressure groups-are present in the Austrian case, they combine in a way very different from how, for example, Go and Lindert $(2007,2010)$ have described the rise of American public schooling. In any country, the buildup of a modern education system was an extensive and onerous task, involving a complex interaction between the economic and political spheres and numerous margins on which decisions had to be taken. That is why attention to detail is of some importance. We hope to have provided such detailed context.

Funding This research was undertaken with the support of a research grant no. 15-16481S from the Grant Agency of the Czech Republic (Grantová Agentura České Republiky (CZ)) and grant no. 14/2015 from NF Neuron (http://www.nfneu ron.cz/en).

Open Access This article is distributed under the terms of the Creative Commons Attribution 4.0 International License (http://creativecommons.org/licenses/by/4.0/), which permits unrestricted use, distribution, and reproduction in any medium, provided you give appropriate credit to the original author(s) and the source, provide a link to the Creative Commons license, and indicate if changes were made. 


\section{Appendix: Measuring literacy content of local labor market}

Table 10 Assignment of occupations to various literacy categories

\begin{abstract}
Literacy required $(L=1)$
Priests and nuns, public sector clerks, army officers, teachers, students, writers, artists, lawyers, doctors, surgeons, midwives, pharmacists, sanitation workers, clerks in the private sector*, entrepreneurs and business owners*, employees in finance

Literacy likely to be useful $(L=0.7)$

Employees in the trading sector, rentiers and renters of real property Occupations with possible (or ambiguous) use of literacy $(L=0.3$ )

Farmers, sharecroppers, laborers*, domestic service

Occupations unlikely to use literacy $(L=0)$

Agricultural laborers and farm servants, fishermen, industrial laborers*, those without occupation
\end{abstract}

The assignments are based on Mitch (1992: 213-214). The * denotes those occupations which in the original document are further disaggregated into various sectors (e.g., 8 separate industrial sectors)

\section{References}

Aghion P, Persson T, Rouzet D (2012) Education and Military Rivalry. NBER working paper \#18049

Bandiera O, Mohnen M, Rasul I, Viarengo M (2016) Nation-building through compulsory schooling during the age of mass migration, mimeo. London School of Economics

Becker SO, Woessmann L (2009) Was Weber Wrong? A human capital theory of protestant economic history. Q J Econ 124(2):531-596

Becker SO, Hornung E, Woessmann L (2011) Education and catch-up in the industrial revolution. Am Econ J Macroecon 3(3):92-126

Bils M, Klenow PJ (2000) Does schooling cause growth? Am Econ Rev 90(5):1160-1183

Chaudhary L, Musacchio A, Nafziger S, Se Yan (2012) Big BRICs, weak foundations: the beginning of public elementary education in Brazil, Russia, India and China. Explor Econ Hist 49(2):221-240

Cinnirella F, Hornung E (2016) Landownership concentration and the expansion of education. J Dev Econ 121:135-152

Cinnirella F, Schueler R (2016) Nation building: the role of central spending in education. CESifo working paper \#6103

Clark G (2007) A farewell to alms: a brief economic history of the world. Princeton University Press, Princeton

Cvrcek T (2013) Wages, prices, and living standards in the habsburg empire, 1827-1910. J Econ Hist 73(1):1-37

Cvrcek T, Zajicek M (2018) The making of a liberal education: political Economy of Austrian School reform, 1865-1875. Explor Econ Hist (forthcoming)

de Pleijt A, Nuvolari A, Weisdorf J (2018) Human capital formation during the first industrial revolution: evidence from the use of steam engines. CEPR Discussion Paper No. DP12987, June 2018

Demian JA (1804) Darstellung der Oesterreichischen Monarchie nach den neuesten statistischen Beziehungen

Demian J (1820) Statistik des Oesterreichischen Kaiserthums. Schwickert, Leipzig

Diebolt C, Charlotte Le C, Menard AR (2017) Industrialization as a deskilling process? Steam Engines and Human Capital in XIXth Century France. Bureau d'Economie Théorique et Appliquée working paper \#2017-17

Easterlin R (1981) Why isn't the whole world developed? J Econ Hist 41(1):1-19 
Engelbrecht H (1986) Geschichte des österreichischen Bildungswesens. Band 3: Von den frühen Aufklären bis zum Vormärz. Wien

Ficker A (1873) Bericht uber osterreichisches Unterrichtswesen. Aus Anlass der Weltausstellung. Alfred Holder, Wien

Franck R, Galor O (2017) Technology-skill complementarity in early phases of industrialization. NBER working paper \#23197

Frank F (1898a) Die Österreichische Volksschule von 1848-1898. Verlag von Pischler's Witwe und Sohn, Wien

Frank F (1898b) Kurzer Überblick über die geschichtliche Entwicklung des österreichischen Volksschulwesens in den letzten fünfzig Jahren. In: Zur Geschichte und Statistik des Volksschulwesens im Inund Auslande, Wien: Sonderausstellungs-Commission "Jugendhalle" pp 60-78

Galor O (2011) Unified growth theory. Princeton University Press, Princeton

Gallego FA (2010) Historical origins of schooling: the role of democracy and political decentralization. Rev Econ Stat 92(2):228-243

Galor O, Moav O, Vollrath D (2009) Inequality in landownership, the emergence of human-capital promoting institutions, and the great divergence. Rev Econ Stud 76(1):143-179

Glaeser EL, Ponzetto GAM, Shleifer A (2007) Why does democracy need education? J Econ Growth 12:77-99

Glewwe PW, Hanushek EA, Humpage SD, Ravina R (2011) School resources and educational outcomes in developing countries: a review of the literature from 1990 to 2010 NBER Working Paper No. 17554 October 2011

Go S, Lindert P (2010) The uneven rise of American public schools to 1850. J Econ Hist 70(1):1-26

Go S, Lindert P (2007) The curious dawn of American public schools. NBER working paper \# 13335

Goehlert JV (1854) Die Ergebnisse der in Österreich im vorigen Jahrhundert ausgeführten Volkszahlungen im Vergleiche mit jenen der neuern Zeit. Sitzungsberichte der philos.-histor. Classe der kais. Akademie der Wissenschaften XIV, pp 52-81

Goehlert JV (1879) Entwicklung der Bevolkerung von Steiermark seit 1754. Statistische Monatschrift 5, 1879, pp 59-64

Goehlert JV (1880) Entwicklung der Bevolkerung von Tirol und Vorarlberg seit 1754. Statistische Monatschrift 6, 1880, pp 52-64

Goehlert JV (1882) Entwicklung der Bevolkerung Krains seit dem vorigen Jahrhundert. Statistische Monatschrift 8, pp 184-191

Goldin C, Katz L (2008) The race between education and technology. Harvard University Press, Cambridge

Goni M (2017) Landed elites and education provision in England: evidence from school boards, 187099, working paper

Hain J (1852) Handbuch des Statistik des Österreichischen Kaiserstaates. Tendler \& Compagnie, Vienna

Hanushek EA (2013) Economic growth in developing countries: the role of human capital. Econ Educ Rev 37:204-212

Hanushek E, Woessmann L (2012) Do better schools lead to more growth? Cognitive skills, economic outcomes, and causation. J Econ Growth 17(4):267-321

Hassel G (1807) Statistischer Abriss des Österreichschen Kaisertums nach seinem neuestern politischen Beziehungen. Friedrich Campe, Nürnberg and Leipzig

Helfert JAV (1860) Die österreichische Volksschule: Geschichte, System, Statistik - I. Band. Prague

Kaiser J (1852) Lehrer-Schema oder Ausweis der sämmtichen, inder Erzdiöcese Wien and bischöfl. Diöcese St. Pölten befindlichen, und an öffentlichen und Privatschulen, an Lehr- und ErziehungsAnstalten, welche der k.k. Landesschulbehörde von Nieder-Österreich understehen, angestellten Lehr-Personales, mit Einschluß der weiblichen Arbeits-, Näh-, Musik-, Sprach- und Zeichnungsschul-Inhaber. Pichler's Witwe \& Sohn, Vienna

Karníková L (1965) Vývoj obyvatelstva v českých zemích 1754-1914. Nakladatelství Československé akademie věd, Praha

K.K. Statistische Zentral-Commission (1852) Die Dampfmaschinen der Oesterreichischen Monarchie zu Ende des Verwaltungsjahres 1851. Mittheilungen aus der Gebiet der Statistik 1(3), Vienna

K.K. Statistische Zentral-Commission (1864) Die Dampfmaschinen der Oesterreichischen Monarchie nach de rim Jahre 1863 vorgenomennen Zahlung. Mittheilungen aus der Gebiet der Statistik 11(2), Vienna

K.K. Statistische Zentral-Commission (1867) Statistisches Jahrbuch der Oesterreichischen Monarchie für das Jahr 1865. Kaiserlich-Königliche Hof- und Staatsdruckerei, Vienna 
K.K. Statistische Zentral-Commission (1870) Detail-Conscription der Volksschulen der im Reichsrathe vertretenen Konigreichen und Landern nach dem Stande vom Ende des Schuljahres 1865. Vienna

K.K. Statistische Zentral-Commission (1871) Bevölkerung und Viehstand der im Reichsrathe vertretenen Königreiche und Länder, dann der Militärgrenze nach der Zählung vom 31. Dezember 1869. Kaiserkönigliche Hof- und Staatsdrückerei, Vienna

Kneidl F (1898) Paměti škol okresu karlínského. J. Otta, Praha

Kudler J (1821) Steyermarks Volkszahl in den Jahren 1819 und 1820 nebst vergleichenden Rückblicken auf frühere Jahre. Steyermärkische Zeitschrift 1(1821):116-153

Lacroix J (2018) Steam democracy up! Industrialization-led opposition in Napoleonic plebiscites. Eur Rev Econ Hist 22(2):135-160

Lindert P (2004) Chapter 5-The rise of mass public schooling before 1914. In: Growing public: social spending and economic growth since the eighteenth century. Cambridge University Press, 2004, pp $87-127$

Lott JR Jr (1999) Public schooling, indoctrination and totalitarianism. J Polit Econ 107(S6):S127-S157

Mariscal E, Sokoloff K (2000) Schooling, suffrage and the persistence of inequality in the Americas. In: Haber S (ed) Political institutions and economic growth in Latin America: essays in policy, history and political economy. Hoover Institution Press, Stanford, pp 159-218

Maschek L (1880) Zur Geschichte und Praxis der Volkszählung in Dalmatien. Statistische Monatschrift 5:351-356

Melton JVH (1988) Absolutism and the eighteenth century origins of compulsory schooling in Prussia and Austria. Cambridge University Press, Cambridge, England

Mitch D (1992) The rise of popular literacy in Victorian England: the influence of private choice and public policy. University of Pennsylvania Press, Philadelphia

Mitch D (1999) The role of education and skill in the British industrial revolution. In: Mokyr J (ed) The British Industrial Revolution: an economic perspective, 2nd edn. Westview, Boulder, pp 241-279

Mitch D (2012) Landed society, farm size, and support for public schooling in nineteenth century England. Working Paper

Mokyr J (2005) Long term economic growth and the history of technology. In: Philippe A, Durlauf S (eds) Handbook of economic growth, vol 1B. Amsterdam, Elsevier, pp 1113-1180

Mokyr J, Voth H-J (2010) Understanding growth in early modern Europe. In: Stephen B, O'Rourke K (eds) The Cambridge economic history of Europe. Cambridge University Press, Cambridge, pp $7-42$

Musacchio A, Fritscher AM, Viarengo M (2014) Colonial institutions, trade shocks, and the diffusion of elementary education in Brazil, 1889-1930. J Econ Hist 74(3):730-766

Nafziger S (2011) Did Ivan's vote matter? The political economy of local democracy in Tsarist Russia. Eur Rev Econ Hist 15(3):393-441

Palma N, Reis J (2018) Can autocracy promote literacy? Evidence from a cultural alignment success story. CEPR discussion paper 12811

Prausek V (1868) Die Verbesserung der Volksschule mi besondere Berucksichtigung Oesterreichs. Sallmayer \& Co., Wien

Pritchett L (2013) The rebirth of education: schooling ain't learning. Brookings Institution Press, Baltimore

Pritchett L, Viarengo M (2015) The state, socialization, and private schooling: when will governments support alternative producers? J Dev Stud 51(7):784-807

Ramcharan R (2010) Inequality and redistribution: evidence from U.S. counties and states, 1890-1930. Rev Econ Stat 92(4):729-744

Ramirez FO, Boli J (1987) The political construction of mass schooling: European origins and worldwide institutionalization. Sociol Educ 60(1):2-17

Sala-i-Martin X (1997) I just ran two million regressions. Am Econ Rev Am Econ Assoc 87(2):178-183

Sokoloff KL, Engerman SL (2000) History lessons: institutions, factor endowments, and paths of development in the new world. J Econ Perspect 14(3):217-232

Springer J (1840) Statistik des österreichischen Kaiserstaates. Fr. Beck's Universitäts-Buchhandlung, Vienna

Vollrath D (2013) Inequality and school funding in the rural United States, 1890. Explor Econ Hist 50:267-284 
von Liechtenstern JMF (1803) Archiv für Geographie und Statistik ihre Hülfswissenschaften und Literatur, vol 1. Verlag des Kunst- und Industrue-Comtoirs, Vienna

von Liechtenstern JMF (1817) Handbuch der neuesten geographie des Österreichischen Kaiserstaates, Vols. 1-3. B. Ph. Bauer, Vienna

Weiss A (1904) Geschichte der Österreichischen Volksschule 1792-1848. Verlagsbuchhandlung Styria, Graz 